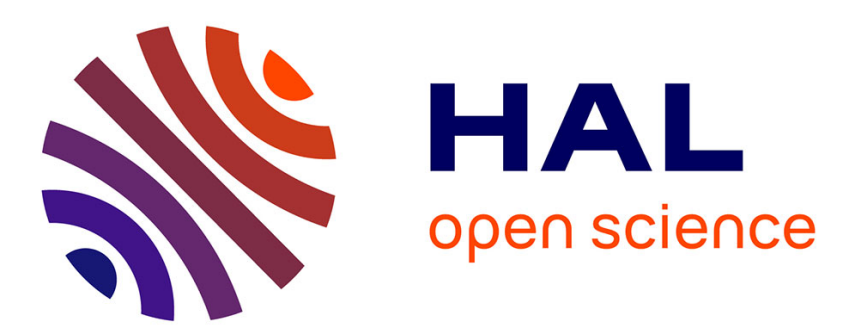

\title{
European Civil Societies Compared: Typically German-Typically French?
}

Edith Archambault, Eckhart Priller, Annette Zimmer

\section{To cite this version:}

Edith Archambault, Eckhart Priller, Annette Zimmer. European Civil Societies Compared: Typically German-Typically French?. Voluntas: International Journal of Voluntary and Nonprofit Organizations, 2014, 25 (2), pp.514-537. 10.1007/s11266-013-9349-6 . halshs-00797886

\section{HAL Id: halshs-00797886 \\ https://shs.hal.science/halshs-00797886}

Submitted on 7 Mar 2013

HAL is a multi-disciplinary open access archive for the deposit and dissemination of scientific research documents, whether they are published or not. The documents may come from teaching and research institutions in France or abroad, or from public or private research centers.
L'archive ouverte pluridisciplinaire HAL, est destinée au dépôt et à la diffusion de documents scientifiques de niveau recherche, publiés ou non, émanant des établissements d'enseignement et de recherche français ou étrangers, des laboratoires publics ou privés. 


\section{Voluntas: International Journal of Voluntary and Nonprofit European Civil Societies Compared: Typically German - Typically French? --Manuscript Draft--}

Manuscript Number:

Full Title:

Article Type:

Keywords:

Corresponding Author:
VOLU-D-12-00106R1

European Civil Societies Compared: Typically German - Typically French?

Research Papers

Civil Society and the nonprofit sector in France and in Germany; comparative analysis; legacies of history in France and Germany

Annette Zimmer

University of Muenster

Muenster, GERMANY

Corresponding Author Secondary Information:

Corresponding Author's Institution:

University of Muenster

Corresponding Author's Secondary Institution:

First Author:

Edith Archambault

First Author Secondary Information:

Order of Authors:

Edith Archambault

Eckhard Priller

Annette Zimmer

Order of Authors Secondary Information:

Abstract:

According to the "social origin theory" of civil society studies (Salamon/Anheier 1998), the nonprofit sector of today constitutes a "repository of former societal struggles and conflicts". Correspondingly, nonprofits are embedded in administrative and organizational settings, which in many cases date as far back as the latter half of the 19th century - a time when industrialisation and urbanisation started to exert influence in the western world. France and Germany stand for very different societal traditions, political legacies and administrative structures. Traditionally, France is a highly centralized country in which local governments do not enjoy much autonomy. In contrast, Germany is a federalized country where self-government of local communities was introduced as early as at the beginning of the 19th century. Against this background, it comes as a surprise that, aside from few exceptions, the nonprofit sectors in the two countries are very similar. How does this come? We argue that the reason why the French nonprofit sector of today is very similar to the German nonprofit sector is closely linked to the growth of the welfare state in the two countries. 


\section{European Civil Societies Compared: Typically German - Typically French ?}

Edith Archambault / Eckhard Priller / Annette Zimmer

Prof. ém. Edith Archambault

Université de Paris 1 -

Panthéon Sorbonne

Centre d'Economie de la Sorbonne

12 place du Panthéon / 75005 Paris

archamb@univ-paris 1.fr

Dr. sc. Eckhard Priller

Prof. Dr. Annette Zimmer

Westfälische Wilhelms-Universität

Münster

Wissenschaftszentrum für Sozialforschung

Berlin (WZB)

Reichpietschufer 50

Institut für Politikwissenschaft

Berlin

Scharnhorststraße 100

priller@wz-berlin.de

48151 Münster

zimmean@uni-muenster.de 
We would like to thank the reviewers for their thoughtful comments.

It was difficult to address the issues, mentioned by reviewer I without changing the paper thoroughly. We tried to extend the paragraph focusing on civil society traditions in the two countries. Indeed, it would be worth writing a paper exclusively on this topic.

We abstained from comparing specific policy fields. Again, it would be a very valuable endeavor to compare specific policy fields. However, the goal of this paper is to provide a broad picture. We tried to add more information on the topic of the so-called feminization of the third sector. For sure, feminization is a central feature of the service industry. However, we tried to highlight that nonprofit organizations increasingly employ women and that these organizations stand more and more for so-called "odd jobs", and hence are working with work contracts that increasingly are temporary and not well-paid.

We hope that we were able to achieve both to improve the language of the article (reviewer II) and to be more specific with respect to the titles of the figures.

In the two countries, the growth of the sector was a by-product of the extension of the welfare state. In Germany, this development was legitimized by referring to the principle of subsidiarity, in France, the government related this development to the approach of "decentralization". The explanation put forward by Kendall/Knapp and Forder does not thoroughly fit the German or the France situation.

We tried to provide more statistical information on the German case. However, currently there is no data available that allows making available a clearer picture of the division of labor between volunteers and employees in German nonprofits. In particular, there is a lack of reliable statistical information with respect to volunteers working for nonprofits.

We added more information on the fields of volunteer activity in France. We also tried to give more information on French foundations.

The reasons why we did not go further into detail on the last topic, listed by reviewer II are twofold: Firstly, in both countries the sector as such suffers from the retrenchment and change of the welfare state. Our aim was to highlight in particular this development. In France and even more distinctive in Germany, we observe a so-called blurring of boundaries, and hence a trend that nonprofits and forprofts are getting more and more alike. From our point of view, how this plays out in France and particularly in Germany should be addressed by a new paper instead of adding a few sentences in the summary 


\title{
European Civil Societies Compared: Typically German - Typically French?
}

\begin{abstract}
According to the "social origin theory" of civil society studies (Salamon/Anheier 1998), the nonprofit sector of today constitutes a "repository of former societal struggles and conflicts". Correspondingly, nonprofits are embedded in administrative and organizational settings, which in many cases date as far back as the latter half of the 19th century - a time when industrialisation and urbanisation started to exert influence in the western world. France and Germany stand for very different societal traditions, political legacies and administrative structures. Traditionally, France is a highly centralized country in which local governments do not enjoy much autonomy. In contrast, Germany is a federalized country where selfgovernment of local communities was introduced as early as at the beginning of the $19^{\text {th }}$ century. Against this background, it comes as a surprise that, aside from few exceptions, the nonprofit sectors in the two countries are very similar. How does this come? We argue that the reason why the French nonprofit sector of today is very similar to the German nonprofit sector is closely linked to the growth of the welfare state in the two countries.
\end{abstract}

\section{Introduction}

France and Germany embody diverging societal traditions, political legacies and administrative structures. Traditionally, France has been a country with a high degree of central authority - as a consequence local governments do not have substantial amounts of autonomy. In contrast, Germany is a federal country where self-government of local communities was introduced as early as at the outset of the $19^{\text {th }}$ century. Moreover, heterogeneity in terms of religious groups, regional and cultural differences has always been a central feature of Germany. France, however, has always been portrayed as a textbookexample of a catholic society, governed by a powerful administrative elite. Germany stands for a tradition of "third party government" or neo-corporatism, which translates into a government cooperating closely with the nonprofit sector with respect to policy formulation as well as policy implementation (Zimmer 1999; Zimmer et al 2009). On the other hand, neocorporatism has never been a feature of the French political culture.

Against this background and disregarding a few minor exceptions, it comes as a surprise that the nonprofit sectors in both countries are very similar. What could be the reason for this? We argue that the reason why today's French nonprofit sector is very similar to the German nonprofit sector is closely linked to the growth of the welfare state. The driving force, which eradicated features of "typical German" and "typical French" in policy implementation, was the aim of both governments to provide citizens with a broad spectrum of social services. However, faced with significant fiscal constraints, a contraction of the economy and a worldwide paradigmatic shift in welfare state policies since the 1990s, German governments 
have significantly altered their attitudes towards the sector. Most recent developments in France and in Germany, therefore, give way to the question whether the success-story of nonprofits in the neighbouring countries might be coming to an end.

The following paper firstly provides a historical overview of the traditions of nonprofit embeddedness in France and Germany. Furthermore, it focuses on the issue of how governments in France and Germany have traditionally - as well as during the heyday of the welfare state - made use of the sector. Secondly, a comparative statistical portrait of the sector in the two countries uncovers striking similarities. Yet, it also illustrates that there are some remaining differences. Finally, the concluding chapter addresses the topic of how government-nonprofit relations will further develop in the two countries

\section{Developments and State of the Art of the Nonprofit Sector in France and Germany}

\subsection{State -Nonprofit Relationships in the $19^{\text {th }}$ Century:} Aloofness in France - Embracement in Germany

Statism, state control and centralisation are the most important features and long-term trends in French history. The millennium fight of the central state against any form of local power is at the root of French centralisation. French kings fought against feudal order and against urban citizens' organisations during the Middle Ages; they fought against regional governments and religious minorities such as Protestants and Jews during the $17^{\text {th }}$ and $18^{\text {th }}$ centuries. Furthermore, French statehood is based on the notion of a direct and close link between the state and its citizens. In accordance with both the political philosophy of Jean Jacques Rousseau and the ideas of the French Revolution, intermediaries such as guilds, fraternities or any kind of voluntary association were supposed to be in the way and hence counterproductive with respect to free trade and modern polity and society. This very notion of statehood was enshrined in the famous Loi le Chapelier of 1791: "No one shall be allowed to arouse in any citizen any kind of intermediate interest and to separate him from the public weal through the medium of so-called common interests" (Archambault 1997: 28; Rosanvallon 2004).

During the $19^{\text {th }}$ century, liberal legislation tended to loosen the reins on intermediaries, such as mutual societies, trade unions or business associations. However, over the course of the century the successive French monarchies and republics kept a critical eye on any societal movement or organisation that did not belong to the realm of the state, such as the labour movement, the Catholic Church or political clubs. Finally, one has to keep in mind that - on a global scale the development of a non-profit sector and the rapid growth of voluntary associations was a byproduct of industrialisation and urbanisation in the $19^{\text {th }}$ century. At that time, associations were 
an urban phenomenon. However, it might be questioned whether the concept of "industrial revolution" that translates into rapid demographic growth, urbanisation and a decreasing economic significance of agriculture can be applied to France which in the second half of the $19^{\text {th }}$ century and the first half of the $20^{\text {th }}$ century was still a rural nation with only a few industrial and densely populated cities or metropolis (Archambault 1997: 30; Archambault 2001).

Compared to France, German government - nonprofit relationships were very different in the $19^{\text {th }}$ century. With the introduction of self-government at the local level in Prussia, German governments started to work with nonprofits by using them as tools of public policy. Faced with the risk of bankruptcy after the Napoleonic Wars, the Prussian State, the largest political entity among the numerous German kingdoms, dukedoms and serfdoms, started a remarkable administrative reform that - among other administrative reforms - introduced the concept of local self-government. Responsibility for local affairs - in terms of societal, political and financial issues - was handed over to the local communities. This meant that the government in Berlin was no longer responsible for the financing of local welfare. Moreover, Berlin also relieved itself of the right to interfere directly in local affairs (Bogumil/Holtkamp 2006). From the very beginning of self-government, due to the lack of resources, local governments had to co-operate with local charities, nonprofit organisations or social entrepreneurs (Sachße 1995; Zimmer et al 2009). The Prussian approach towards self-government at the local level set a precedent that was copied, albeit with stark regional and local modification, throughout Germany in the $19^{\text {th }}$ century. Against this background, although a strong state or etatism constitutes a central feature of German tradition, "intermediaries" such as guilds and fraternities, nonprofit organisations and voluntary associations were not perceived as threats to the modernization of the state in the $19^{\text {th }}$ century. On the contrary, in Germany, parts of the emerging nonprofit sector were smoothly and very successfully integrated into modernising strategies that were initiated and supervised by the state and its growing administration. Germany's nonprofit sector in the $19^{\text {th }}$ century constitutes a prime example of a sector which developed and flourished "under the thump" of the state. The sector provided room for a "private culture of welfare" (Sachße 1996) of numerous initiatives without endangering state authority.

The reason why a lively nonprofit sector operated successfully in an authoritarian regime is closely linked to the ideas of the political philosophy of Friedrich Hegel. According to his logic and in sharp contrast to the ideas of the French Revolution, Hegel differentiated between the realm of the state and that of society. While the State is responsible for the common good, civil society or bürgerliche Gesellschaft constitutes the space where citizens through Korporationen and hence membership organisations are able and allowed to follow their specific interests. However, the state guarantees that "private interests" will not get out of 
hand. Hegel promoted the concept of a strong state and a strong civil society. But, the Hegelian civil society operates under the tutelage of the state. Having this concept in mind, it follows logically that an integration of nonprofit organisations into state-initiated and supervised policies does not endanger state authority. On the contrary, working closely with nonprofits supports the advancement of state authority because this provides government initiatives with societal legitimacy (Strachwitz 2010: 87ff).

\subsection{State - Nonprofit Relationships in the Period of Welfare State Expansion: France Following the German Model}

Against this background, the German tradition of neo-corporatism which traditionally assigns societal bodies, such as trade unions, business associations and nonprofit charities, an important role in the policy process becomes understandable (Streeck 1999; Lehmbruch; 1996; Katzenstein 1987). Without going into detail, the initially local approach of third party government (Salamon 1987) that translates into policy making in close co-operation with as well as through nonprofit organisations, has been upgraded to the national level as early as the late $19^{\text {th } /}$ and early $20^{\text {th }}$ century. What modern political scientists label as neo-corporatism governing with the assistance of associations at any level of government and in a broad spectrum of policy fields - has had a long tradition in Germany.

During the period of welfare state expansion, Germany, in accordance with path-dependency, strongly built on the country's tradition of close partnerships between governments and nonprofit organisations - particularly in core welfare areas but also in other policy fields such as leisure or sports. In the aftermath of World War II, neo-corporatism, which some political scientists also title meso-corporatism, developed into the overall strategy of policy making in Germany. At the national or Federal level of government, policy field specific umbrella organisations such as the Welfare Associations or the German Olympic Sports Association were and still are thoroughly integrated into the policy process. At the Federal and regional level, representatives of these "umbrellas" work on par with representatives of government administration and politicians. At the local level on the other hand, the membership organisations of the umbrellas - hence the local sport clubs or the organisations and institutions of the Welfare Associations - are thoroughly integrated into the process of policy implementation. Funding is safeguarded and regulated by the Federal Government in the core welfare domain; funding for leisure and sports is the responsibility of local governments and is thus dependent on their respective financial liquidity.

The German version of "third party government" translated into a remarkable success-story of the nonprofit sector in the core welfare domain as well as in the area of sports and leisure. The German Welfare Associations developed into the most important providers of social services. 
Moreover, the success story of the German sport clubs is outstanding. There are more than 95.000 active sports clubs in Germany (Zimmer et al 2011). The core of the "German model" encompasses decentralised provision of services as a joint endeavour of public-non-profit cooperation and centralised policy formulation with the aim of providing a framework for policy enactment without going into details and hence granting communities and regions some leeway for manoeuvring.

Doubtlessly, the German model influenced the French approach towards the nonprofit sector and its organisations - at least to a certain extent. At the outset of the $20^{\text {th }}$ century (1901), the freedom of association was legally safeguarded in France. Similar to Germany, the development of the sector as well as its significant growth and flourishing went hand in hand with the build-up and expansion of the nation's welfare state, which started in the aftermath of World War II and particularly since the 1960s.

From this decade onward, there is a trend in France of less state control. More attention has been paid to developments in other continental European countries. The first Decentralisation Act (1983) was a way to aspire to a more European political structure. In France, decentralisation has been introduced quite recently, yet it seems to have been a strong incentive for the current nonprofit sector development. Reducing the prerogatives of the central government to the benefit of regions, departments and local communities, decentralisation has given way to a new kind of partnership between nonprofit organisations and local authorities in France.

In other words, instead of neglecting or even oppressing private nonprofit initiatives, French governments have increasingly started to co-operate with the sector and its organisations. Step by step, the areas of co-operation were expanded. In the 1950s, nonprofits supporting physically or mentally handicapped citizens and social tourism associations running holiday resorts for the working class were acknowledged by the government as legitimate providers of general interest services. In the 1960s, nonprofits enhancing the democratisation of sports and culture as well as multipurpose associations disseminating popular culture were encouraged and supported by the government. In the 1980s and 1990s with significant government support, many nonprofits were created to cope with social exclusion by providing work to unemployed citizens. Moreover, against this benevolent background, fine examples of social entrepreneurship came to the fore in France. A case in point is the organisation Medecins sans frontières, the famous "French doctors", which were awarded the Nobel Peace Prize. Most recently, government support through tax incentives and subsidies gave rise to the establishment of many home care services and other facilities for an ageing society that are provided and managed primarily by nonprofits. 
The embracement of the sector by the welfare state resulted in both countries in a successstory as well as a remarkable growth of nonprofit organisations. In France and in Germany, today's non-profit sector constitutes a highly integrated component of each country's welfare state. Alongside with the growing importance of social policy and particularly social service provision, nonprofit organisations developed into important tools of political engineering. The following statistical portrait of the two sectors reveals a picture of striking similarity.

\section{Statistical Profile of the Nonprofit Sectors in France and Germany 3.1 Nonprofit Growth in France and Germany}

A common feature of the sector in both countries is its remarkable growth, particularly since the mid 1970s. In quantitative terms, nonprofit organisations in France and Germany look back upon a success-story of accelerated growth that resulted in a development boom with respect to the establishment of nonprofit organisations.

Figure 1: Increase of the number of voluntary associations in Germany, 1960 - 2011

Sources: Johns Hopkins Comparative Nonprofit Sector Project, 2001-2011: V \&M Service GmbH, Konstanz, Germany; Priller 2013

In Germany, the majority of nonprofits are legally "chartered associations" (eingetragene Vereine). According to the results of the Hopkins Project, the number of these associations has increased more than six-fold from 86.000 in 1960 (former West Germany only) to over 550.000 in 2008 and 580.000 in 2011. This "associational boom" outmatched the growth rates of both public entities and for-profit companies (Zimmer/Priller 2007: 55). Although there are many nonprofit organisations in Germany, as local studies show (Zimmer 2007), that are dating back to the early $19^{\text {th }}$ century, the vast majority of German nonprofits has been established over the last four decades in what is formerly West-Germany - whereas in what was formerly East-Germany this development could only be observed over the last two decades. Approximately, every second nonprofit organisation - approximately 300000 employs personnel while almost every German nonprofit - about $97 \%$ in fact - works with volunteers (Priller et al. 2012).

France has experienced an identical success-story with regard to non-profit growth over the last decades. Similarly, "association" constitutes the generic legal form of the majority of French nonprofits. Starting in the late 1970s, the result of the non-profit boom has been that by now between 60.000 and 70.000 associations are founded every year - more than three times the average that was achieved in the 1960s. 
Figure 2: Annual Foundation of Associations, 1960 - 2011

Source: Ministère de l’Intérieur, Journal officiel (except Departement Alsace-Moselle)

Today, there are about 1.200 .000 associations operating in France. The vast majority - similar to Germany - are small and locally active organisations, which are working either exclusively with volunteers or with very few paid employees. Overall, there are a mere 160.000 associations that are managed by professional staff; 2.000 associations have been granted the "Reconnue d'Utlité Publique" by the French government that is a special legal form guaranteeing full legal status. In contrast to other associations, the Reconnue d'Utlité Publique nonprofits are eligible for renting property or having profitable financial assets

\subsection{Integration into the Welfare State}

In both countries, nonprofit social service providers are the strongholds of the sector in terms of economic activity and nonprofit employment. In France, the majority of nonprofit employees are working in organisations which are active in the core welfare areas, particularly in the fields of social services, education and health.

Table I: Nonprofit Organisations and Nonprofit Employment by Activity, $2009^{1}$

Source: INSEE, Tableaux harmonisés de l'Economie sociale

Every second employee who works in the French nonprofit sector is affiliated with a nonprofit organisation, active in social services. In addition, in this core area of welfare provision $60 \%$ of the workforce is employed by a nonprofit organisation. Nonprofit employment in health and education, which constitutes a public domain in France, is comparatively much less pronounced than it is in the area of social services. Nevertheless, nonprofit employment is also significant in these core welfare fields. Outside the welfare areas, the nonprofit sector is a major employer in culture, sports as well as recreational activities

The same holds true for Germany. Once more, the core welfare domain constitutes the stronghold of economic activity and employment of the German nonprofit sector. According to the most recent study of the German nonprofit sector, the areas of health and social services account for more than two thirds of the gross value of nonprofit activity in Germany.

\footnotetext{
${ }^{1}$ The term nonprofit encompasses associations and foundations. It does not cover nonprofit establishments run by mutuals. According to an agreement between INSEE and CNCRES to define the scope of social economy, the term does not include worship organizations, political parties, labour unions, and business and trade unions.
} 
Figure 3: Areas of Nonprofit Activity and Gross Value Added, in $\%^{2}$

Source: Krimmer 2011: Zivilgesellschaft in Zahlen

Indeed, the similarity between Germany and France with respect to nonprofit employment is striking. In Germany, nonprofit employment is concentrated in the social service domain. According to the results of the Johns Hopkins Project, the area of health and social services absorb about $60 \%$ of the sector's workforce, with social services getting ahead of the area of health in recent years. Similar to the U.S., German NPO-hospitals once used to be the stronghold of nonprofit employment (Zimmer/Priller 2007: 57). However, the for-profit sector has made significantly inroads into this traditional area of nonprofit activity over the last decades in Germany (Henriksen et al 2012). Currently, the nonprofit sector accounts for 76 $\%$ of total employment in the area of social services (Sozialwesen). Whereas, in the field of health, just $25 \%$ of the labour force is employed by nonprofits. The shares of nonprofits in the fields of leisure and sports amount to $31 \%$ of total employment (Priller 2013; Rosenski 2012; Krimmer 2011).

The vast majority of employees working in the area of health and social services in Germany are employed by a membership organisation of the famous German Welfare Associations. The Associations are key players in the German welfare state with a special focus on social service provision. They are "umbrellas" with - as indicated in Table IV - thousands of affiliated (membership) organisations operating locally. These Associations - such as Caritas, Diaconia, German Red Cross, Parity, Workers' Welfare Association/AWO - were founded at the end of the $19^{\text {th }}$ century. Today they are still organised along normative lines and either affiliated with the Churches (Caritas and Diaconia), the German Social Democratic Party (AWO) or the conservative/liberal spectrum (Red Cross) (Boeßenecker 2005).

Table II: Organizations and Areas of Activity of the German Welfare Associations, 2008

Source: Bundesarbeitsgemeinschaft der Freien Wohlfahrtspflege e.V. (BAGFW) (2009): Einrichtungen und Dienste der Freien Wohlfahrtspflege. Gesamtstatistik 2008.

The Welfare Associations look back upon a remarkable story of growth that started in the late 1960s. The biggest players of the German Welfare Associations are Caritas and Diaconia, which are both affiliated with the two Churches. The same more or less holds true for the functional French equivalents, the private charities of which the majority and the most important ones are federated in UNIOPSS that used to be under a catholic inspiration.

\footnotetext{
${ }^{2}$ Exclusively nonprofits with employees are considered.
} 
However, this is increasingly vanishing with French society becoming increasingly secular. Today, French society is the least religious in Europe (Archambault, 1997; Bode 2003). Hence, similar to the situation in Germany, in France, charities or nonprofit social service providers were gradually integrated into the expanding welfare state when social services developed into a major area of public welfare activity in the late 1960s and early 1970s in Europe.

In both countries, the workforce of the sector is highly concentrated. The "biggest nonprofit employers" in France and Germany are hospitals as well as residential caring homes. In France, the top $2 \%$ of the large nonprofit organisations that employ at least 100 employees account for more than half of the wage bill of the nonprofit sector which amounts to 37 billion of gross wages, or $5 \%$ of the total wage bill of the private and public sectors. Similar to Germany, these large French nonprofits are hospitals, nursing homes and residential facilities for the disabled that are by and large affiliated with the big humanitarian nonprofits - such as the French Red Cross, the Secours Catholique-Caritas or Association des Paralysés de France. Rather similar to France (Tchernonog 2007), two thirds of the German nonprofit employment, according to the results of the most recent study, is concentrated in the areas of health care (hospitals) and social services (retirement, residential or community homes) (Zivis 2011: 65).

In terms of employment, the German nonprofit sector looks back upon a success-story of continuous growth. According to the results of the Johns Hopkins Project, nonprofit employment has more than doubled since the early 1990s in Germany. However, compared to the 1990s, the growth rate of non-profit employment has slowed down in the past decade. In addition, we might face a further slow-down of nonprofit employment in Germany due to both fiscal constraints and increasing competition of for-profit competitors in core nonprofit areas, such as health care.

Table III: Nonprofit Employment in Germany

Source: Johns Hopkins Comparative Nonprofit Sector Project \& Rosenski 2012

\subsection{Feminized Labour Force Working in "Odd Jobs"}

Nonprofit organisations working with professional staff are primarily active in the service industry. This results in the majority of the sector's work force in France and Germany being women. In France, $69 \%$ of the sector's workforce are women - compared to $76 \%$ in Germany (Priller 2013). In France, the percentage of women in the workforce of nonprofit organisations has been steady over the last two decades, however women are often part-time, seasonal or short-term employees and they seldom occupy upper management positions 
(Tchernonog 2007; Richez-Battesti et al 2011). The trend towards an increasingly feminized nonprofit labour force particularly in Germany goes hand in hand with a deterioration of the quality of jobs in the sector. The reasons for this development are closely related to a change of welfare policies.

Instead of working exclusively with nonprofits, the French and German governments have shown an increasing tendency towards enhancing competition between nonprofit and forprofit providers of health and social services. Consequently, increased competition at the level of the organisations translates into a significant increase in part-time employment and a proliferation of temporary employment relationships.

Figure 4: Women, part-time, and temporary employees in Germany's labour force, 1996 and 2008 in \%

Source: IAB Betriebspanel, 1996-2008

The amount of part-time employment in the sector has seen an increase from about 29 $\%$ in 1996 to $49 \%$ in 2008. Thus, part-time employment is more important in nonprofit organisations than it is in the public sector - where it amounts to about $29 \%$ - or in the commercial social services sector - where it accounts for about $38 \%$ of employment. This development can partially be attributed to the rising number of female workers in the third sector. In Germany, women are by and large in favour of part-time employment because they want to reconcile employment and family life. However, a further explanation for the increasing level of part-time employment in the sector is strongly related to cuts in public funding that is closely linked to recent reforms seeking to economise organisations active in the core welfare domain. So-called mini-jobs constitute a special type of part-time employment that is poorly paid and fairly common in the sector. Thus, part-time employment and in particular short term labour contracts are an effect of financial constraints. In 2008 about $15 \%$ of all employment contracts in the third sector were temporary and hence limited in time in Germany.

Indeed, the poor quality of employment in NPOs constitutes another common feature of the French and German nonprofit sectors. In both countries, the percentage of part-time, seasonal and other forms of "odds" or flexible jobs is higher than it is in the other sectors. Furthermore, NPOs welcome the greatest part of the so-called "helped jobs" or government subsidised jobs which are created to cope with problems caused by structural unemployment of specific groups - such as young people in France or long-term unemployed in Germany. The results of most recent studies in Germany show that the quality of employment in the sector is steadily declining. Compared to the public and the for-profit sector, nonprofit organisations hold the largest share of part-time and temporary jobs in Germany. Again, the labour force, employed in these unfavourable jobs, is predominantly female (Priller 2013; Tchernonog 2007). 


\subsection{Finances}

The French and the German nonprofit sectors are both highly dependent on public money or at least publicly regulated income. The reason why public money plays such an important role for nonprofits in both countries has to do with the integration of the sector and more specifically of NPOs, active in welfare related fields, into the countries's systems of social service provision.

In France, nonprofits working with professional staff are predominantly publicly funded. Up to $56 \%$ of their income comes from public sources, more precisely from the national government, from departements, and from the numerous municipalities (36000) as well as from social security. However, NPOs, whose work force are predominately volunteers, are far less dependent on public money which only amounts to $26 \%$ or one fourth of their income. Whatever form of public funding is used, such as subsidies, contracts, or competitive bids, public money by and large goes to those NPOs that are active in the core welfare areas, more specifically in the areas of education, health and social services.

Market income in terms of fees for services accounts for $40 \%$ of the total income of professionalised NPOs working with employees. This share of market income generated through membership fees is most important for non-professionalised NPOs that work exclusively with volunteers. $50 \%$ of their finances are market income, more precisely membership dues. However, also small NPOs that are locally active as well as grassroots organisations receive public support, primarily from local authorities. In contrast to the large professionalised organisations, local French nonprofits, active in the areas of leisure, sports or recreational activities, do not primarily rely on public money (Tchernonog 2007).

In France, the importance of private money in terms of philanthropy or donations as well as support from companies - corporate citizenship programs and sponsorship - for the finances of the sector amounts to just $5 \%$ of total income. There are also some large charities in France that are funded mainly by donations such as Secours Populaire, Restaurants du Coeur, or the famous Médecins sans Frontières, and Médecins du Monde. However, with regard to the overall picture, private funding constitutes a rather symbolic resource for nonprofits in France (Archambault et al 2010).

A split between highly professionalised nonprofits and NPOs that work almost exclusively with volunteers also characterises the German nonprofit sector. The professionalised German NPOs are thoroughly integrated into the country's welfare state. Working in the areas of 
health and social services, they are predominately publicly funded. On the contrary, the vast majority of small nonprofits, active in the areas of leisure and sports work predominantly with volunteers. They also receive small public subsidies, predominantly from local governments as well as infrastructural support in terms of facilities (e.g. sports hall, playing fields). However, their prime sources of finances are membership dues.

In Germany, the largest share of nonprofit funding consists of contract-based payments either from government entities (e.g. municipalities) or from social and health care insurances. Public support in form of subsidies and temporary grants constitutes the second most important source of funding. Earned income - particularly membership dues - has always played an important role, particularly for those organisations that work in fields such as sports or leisure. Similar to France, philanthropy and income from sponsorship of corporations is not very important for the funding of German nonprofit organisations (Zimmer/Priller 2007: 81). However, there are selected organisations, such as Greenpeace Germany, that live thoroughly off donations and earned income, or which rely heavily on donations, such as the NPOs that are active in humanitarian aid activities, such as Caritas International, or Oxfam Germany.

\subsection{On the Advance: Volunteering}

Finally, volunteering as a major resource for nonprofit organisations assumes similar forms in France and Germany. However, in both countries volunteering is by no means restricted to nonprofits. It is increasingly of significant importance for the wellbeing of public organisations, such as publicly run schools, kindergartens or museums. Nevertheless, nonprofit volunteering has developed positively over the last decades in both countries. While Germany looks back upon a stable but comparatively moderate increase in volunteering, in France, volunteering has become more widespread very recently, particularly in the last twenty years. Indeed, the numbers of volunteers doubled since the early 1990s in France. The reasons for this are manifold: It is partly due to a true increase of temporal sacrifices, and partly due to the fact that people who saw themselves as helping or doing alternative civilian service now say that they are volunteering.

Table IV: Development of Volunteering in France, 1990 - 2010

Sources: France - 3 Surveys LES/ISL/JHCNP for 1990, 1993 and 1996; INSEE 2002; DREES-BVA for 2010.

Figure 5: Development of Volunteering in Germany, 1985 - 2009 
Source: Priller 2013

Depending on the approach and method of surveying, response rates slightly differ in Germany. According to the results and data of the German Socioeconomic Panel (SOEP), the share of persons engaged in volunteer activities has developed positively from $22.6 \%$ in 1985 up to $30.3 \%$ in 2009 (see Figure 5). Particularly, regular and very stable engagement that takes place at least once a month, has seen an increase in Germany and France (Prouteau/Wolff forthcoming). The results of the German Freiwilligensurvey reveal an even more positive picture of Germany as an active civil society. According to the Freiwilligensurvey, $36 \%$ of the German population volunteers regularly. Thus, generally speaking, more than every third inhabitant of either France or Germany and, therefore, a significant part of the population of the two neighbouring countries is regularly engaged in volunteer activities - more than one third of Germany's population volunteer regularly, whereas in France two-thirds volunteer occasionally, during holidays or in relation to specific non-profit events such as telethon.

It does not come as a surprise that the areas of volunteer activities are also very similar in France and Germany. Prime areas are sports, leisure and hobby activities as well as culture and recreation. Next to these leisure related fields, volunteers are engaged in social as well as in church related areas. However, Germans are less frequently engaged in areas related to politics, advocacy or community affairs.

Figure 6: Volunteering in Germany According to Fields of Activity, 1999, 2004, and 2009, in Percent of Overall Volunteering

Source: Freiwilligensurvey 1999, 2004, 2009

Table V: Volunteering in France by Fields of Activity, 2006, in \% of Total Volunteering

Source: Tchernonog 2007: Organizations Survey, without religions

France mirrors Germany with respect to the preferred fields of volunteer activity. The French population is engaged in sports $(23 \%)$, culture $(15 \%)$, leisure and recreation $(15 \%)$. Compared to Germany, advocacy organisations attract more volunteers (16\%) in France, while the areas of health and social services $\left(10 \%^{3}\right)$ as well as education and training $(8 \%)$, and religion $(5 \%)$ are more popular fields of volunteer activity in Germany than they are in

\footnotetext{
${ }^{3}$ This classification deals with the members of associations that work also voluntarily for them. But lots of volunteers are not members of the organisation and these volunteers are not classified in the DREES-BVA survey (Prouteau and Wolff forthcoming).
} 
France. In Germany and in France, volunteering is still highly gendered. Men who volunteer prefer sports and professional associations as their prime field of activity. Whereas, women are first and foremost engaged in the areas of health, social services, and education. In contrast to France, German women volunteer very often in church or religiously affiliated organisations.

\subsection{Legacies of History}

Despite the similarities, there are at least two aspects that are different in France and Germany. Each of those is closely linked to the political culture and tradition of the respective country. The first one has to do with Germany's tradition as a "nation of joiners". There is a significant gap between membership quotas in France and Germany according to the results of the European Social Survey. Although almost every second citizen in France was a member of an association, the Germans surpassed the French by $20 \%$ in 2002/2003. $70 \%$ of the Germans interviewed were members of at least one association. But, multiple membership is very frequent in Germany. In the meantime, it is also becoming more frequent than previously in France (Zimmer 2007; Prouteau/Wolff forthcoming).

Figure 7: Membership Quota in Voluntary Associations (Clubs) in European Countries

Source: ESS 2002/2003; Priller 2013

There are many jokes about the German Vereinsmeierei, i.e. the tendency to found voluntary associations or clubs that are membership based for any purpose one can conceive of (Zimmer 2007). Some of these clubs are very old, dating back to the early $19^{\text {th }}$ century such as Reading Societies or Literary Salons; some of them were founded in the second half of the $19^{\text {th }}$ century, such as singing or sport clubs. Some of them are a product of the late $19^{\text {th }}$ and early $20^{\text {th }}$ century, e.g. gardening societies or local church affiliated charities, which were the forrunners of the German Welfare Associations - the most important providers of social services today (see Table II). Membership is at the core of these nonprofit organisations. And although membership in nonprofits is slightly on the decline in Germany, there are still definitely more German than French members of nonprofits, in particular of clubs or membership based voluntary associations.

Furthermore, the sectors of the two countries differ with respect to private contributions, the funding of foundations respectively. According to the results of the European Social Survey, Germans tend to be more engaged in private philanthropy than the French. Every third of the Germans interviewed donated on a regular basis, whereas in France, every fifth person interviewed indicated that private philanthropy is a part of his or her life-style. 
Figure 8: Quota of Donators in European Countries

Source: ESS 2002/2003; Priller 2013

Finally, the difference between France and Germany is impressive with respect to foundations. Again, private philanthropy was a prominent and central feature of modernising Germany in the late $19^{\text {th }}$ century. At that time, many private foundations that were modelled after the American example were founded, in particular in big cities such as Hamburg, Berlin or Frankfurt. Depending on the region, these foundations, however, worked closely together with public administration and local government. Therefore, foundations in Germany did not perceive themselves per se as a counterbalancing force vis-a -vis state power. On the contrary, in many cases, private foundations and local governments share a tradition of working hand in hand with the aim of helping the poor, supporting the arts or institutions of higher education or research. During the German Empire, the establishment of foundations enjoyed governmental support and was perceived as being highly beneficial for the advancement of various segments of German society (Frey 1999). Accordingly, there were many private foundations operating in Germany in the late $19^{\text {th }}$ century, and hence before political and economic turmoil gripped the country with the effect of destroying a rich sector of foundations.

After World War II, it took time to catch up. Nevertheless, in the meantime, Germany has developed into a vivid arena for foundations. Today, Germany is second only to the U.S with respect to the numbers of foundations. There are only about 2.000 foundations operating in France. In contrast, the number of foundations in Germany amounts to about 20.000 (Alscher et al 2009). The growth of the foundation sector has been heavily supported by the German government, which implemented laws that are beneficial and very supportive of private philanthropy in the 2000s (Alscher et al 2009).

Figure 9: New Foundations in Germany, 1990-2011

Source: Bundesverband Deutscher Stiftungen; Priller 2013

Contrary to Germany, the centralised French State has always been suspicious of foundations. Some of them dated back to the Middle Ages and were closely linked to the Catholic Church and its monastic orders. Due to donations and bequests, particularly these foundations became very rich. Even before the French Revolution, Louis XIV and Louis XV viewed foundations as inefficient competitors in the provision of public services. Accordingly, foundations were 
secluding mortmain property from productive economic flows and escaping from property ${ }^{4}$ and other royal taxes. During the Revolution, the properties of both the Church and its affiliated foundations were seized. Many schools and charitable institutions had to be closed, while hospitals were nationalised. In France, foundations virtually disappeared until the end of the $19^{\text {th }}$ century. Very few foundations were created in the $20^{\text {th }}$ century, even after World War II when foundations started mushrooming in other European countries and especially in Germany. In 2005, there were 19 foundations per one million inhabitants in France, next to Ireland the lowest rate in the European Union - this provided a significant contrast to the 156 foundations per one million inhabitants in Germany (European Foundation Centre 2008). However, since 2003, after a law introducing more fiscal incentives for individual and corporate donations was implemented and since 2009, when endowment funds were created, many new corporate and individual foundations have been created in France. In addition, more than one thousand endowment funds have been started since 2009. Despite this very recent improvement, there still is a significant difference between the two countries as regards the culture of philanthropy

Summarizing the results of the statistical profile of the nonprofit sectors in France and Germany, the similarities are impressive. Alongside the growth of the welfare state, "typically French" has shifted towards "typically German". German governments have always made use of "the sector". On the contrary, French governments have only recently discovered the sector as a vehicle for public policy. In the meantime, the German and French nonprofit sectors have become rather similar with the two exceptions of firstly, foundations that in contrast to France are numerous and flourishing in Germany and secondly, membership affiliation which is at the core of political culture in Germany but less common in France. Is this also the case with respect to the topic of how current developments, in particular changing government policies and the fiscal crisis, have an impact on the sector in the two countries?

\section{Current Developments}

Non-profits in France and Germany are currently confronted with similar problems and difficulties. Competition constitutes a major issue for the sector and its organisations in both countries. Due to the significant dependence of nonprofits on public funding in both countries, current cuts in government spending have hit the sector in France and in Germany alike. In Germany, particularly nonprofits working at the local level in areas such as leisure or sports, which do not enjoy legally secured funding, face a difficult situation due to the fiscal constraints of German local governments

\footnotetext{
${ }^{4}$ In the Great Encyclopaedia of the $18^{\text {th }}$ century, Turgot declared: "A founder is a man who wants to eternalize its will [....]No man-made work is everlasting. As foundations, multiplied by vanity, would absorb in the long run all funding and individual property, it is necessary to destroy them."
} 
and are therefore increasingly cut off from an important source of funding. Against this background, small and medium-sized nonprofits are more and more in a situation of fierce competition for local government grants and subsidies. Seeing in the near future, it is likely that the financial crisis will have a stronger impact on Germany, in particular local nonprofits will face a very difficult time. Already today, membership is decreasing in local associations because Germans nowadays tend to avoid unnecessary expenditures such as membership dues for voluntary associations whose services are no longer appreciated and used. A downsizing of the nonprofit sector, less organisations with fewer members and reduced programs of leisure and sport activities might be the most likely outcome of the current situation.

The same holds true for those organisations, working in the core welfare domain such as in social services or health care. Since the mid 1990s, the German government has followed a neo-liberal agenda in social policy. A "privileged partnership" with non-profits in the areas of social service provision is no longer perceived as a successful approach. In accordance with cost-cutting strategies, "competition" among different providers of social services in a selected area, such as hospital care, seems to safeguard efficiency more effectively. Nonprofit hospitals, homes for the elderly, children's homes and other facilities are faced with increasing competition from the forprofit sector in Germany. In order to be eligible for government grants, large and professionalised German nonprofits, active in the core welfare domain, have developed into highly efficient welfare enterprises. From a management point of view, today, there is almost no difference between a nonprofit and for-profit social service provider in Germany.

However, although the German government increasingly treats nonprofits on equal footing with for-profit enterprises, the government still perceives the organisations as alternative tools for policy development. Textbook examples are programs that aim at integrating long-term unemployed, or government sponsored initiatives whose goal is a further integration of members of the migrant community in Germany. In other words, the organisations are perceived as competitors in social markets which are increasingly tougher and simultaneously, nonprofits are supposed to work on behalf of the common weal by running programs and initiatives which primarily serve those parts of the population that are in a very difficult situation, and who first and foremost have very little chances on the non-subsidized labour market. In sum: Currently, German government lacks a coherent policy towards the sector.

Again, the situation of nonprofits in France is similar. The financial crisis has already heavily affected the funding situation of many nonprofit organisations in France. The retrenchment of public money is certainly the most hard-hitting part of the crisis. The reduction of subsidies and contracts paid by the State is no longer being compensated by the regions, the départements or by local communities, all of which also have financial difficulties. Despite tax incentives, donations remain steady with little hope for an increase. During the early stages of the crisis, public grants or 
reimbursements were delayed and sometimes suppressed, provoking at best cash flow difficulties, and at worst bankruptcies along with the dismissal of employees. This has been the case for some home care services and nonprofits, active in the area of culture. In the meantime, the fiscal situation has significantly deteriorated. Against the background, a number of French nonprofits have merged with other organisations working in the same field or area, or they are pooling their infrastructure, equipment or human resources. However, it is very unlikely that the French nonprofit sector will undergo a process of concentration. Instead, it is more likely that employment in the sector will decline. Indeed since 2010, nonprofit employment has been decreasing. This might be an indicator of approaching a turning point in the sector's continuous success-story in France. In 2011, about 26000 jobs were suppressed.

Overall, the outlook towards future developments is rather pessimistic in both countries. It is most likely that the sector's success-story that by and large was a by-product of the growth of the welfare state might come to an end. Nonprofit employment is on the decline. Furthermore, the quality of jobs in the sector is significantly deteriorating. Additionally, the attractiveness of nonprofits for members is declining. The sector in both countries is confronted with a difficult situation, which asks for a new definition of its position vis-a-vis the state and the market. The new French government is now looking for a policy for the social economy, encompassing cooperatives and mutual companies, membership associations and foundations. In 2012, a law on these organisations will be voted on. Moreover, in accordance with the recommendations of the report of the StiglitzSen-Fitoussi Commission (2009), new indicators to measure economic performance and social progress are currently discussed in Europe. Particularly, this new approach tries also to draw the attention to the social as well as to the economic role of nonprofit organisations on both European welfare and the wellbeing of its citizens. 


\section{References:}

Alscher, M., Dathe, D., Priller, E., and Speth, R. (2009). Bericht zur Lage und zu den Perspektiven des bürgerschaftlichen Engagements in Deutschland, WZB, Berlin.

Archambault, E. (1997). The nonprofit sector in France, Manchester Univ. Press, Manchester.

Archambault, E. (2001). Historical Roots of the Nonprofit Sector in France. Nonprofit and Voluntary Sector Quarterly, Vol. 130, No. 2, 204-230.

Archambault, E., Accardo, J., and Laouisset, B. (2010). Connaissance des associations, Report to the CNIS.

Bode, I. (2003). A New Agenda for European Charity: Catholic Welfare and Organizational Change in France and Germany. Voluntas, Vol.14, No. 2, 205-225.

Boeßenecker, K. (2005). Spitzenverbände der Freien Wohlfahrtspflege. Eine Einführung in die Organisationsstrukturen und Handlungsfelder der deutschen Wohlfahrtsverbände, Juventus, Weinheim/München.

Bogumil, J., Holtkamp, L. (2006). Kommunalpolitik und Kommunalverwaltung, VS Verlag, Wiesbaden.

European Foundation Center (2008). Foundations in the European Union. Facts and Figures, Bruessel.

Frey, M. (1999). Macht und Moral des Schenkens. Staat und bürgerliche Mäzene vom späten 18. Jahrhundert bis zur Gegenwart, Fannei\&Walz, Berlin.

Henriksen, L. S., Smith, S. R., and Zimmer, A. (2012). At the Eve of Convergence? Transformation of Social Service Provision in Denmark, Germany, and the United States. Voluntas, Vol. 23, No. 2, 458-501.

Katzenstein, P. J. (1987). Policy and politics in West Germany: the growth of a semisovereign state, Temple Univ. Press, Philadelphia.

Krimmer, H. (2011). Zivilgesellschaft in Zahlen, (6/24/2012): http://www.ziviz.info/fileadmin/download/krimmer_zivilgesellschaft_in_zahlen_projekt ergebnisse.pdf.

Lehmbruch, G. (1996). Der Beitrag der Korporatismusforschung zur Entwicklung der Steuerungstheorie. Politische Vierteljahresschrift, Heft 4, 735-751.

Priller, E. (2013). Scope, Structure, and Development of Civil Society in Germany. In A. Zimmer (ed.): Civil Societies Compared: Germany and the Netherlands, Nomos, BadenBaden (in press).

Priller, E., Alscher, M., Droß, P. J., Paul, F., Poldrack, C. J., Schmeißer, C., and Waitkus, N. (2012). Dritte-Sektor-Organisationen heute: Eigene Ansprüche und ökonomische Herausforderungen. Ergebnisse einer Organisationsbefragung. Discussion Paper SP IV, WZB, Berlin, 2012-402 (www.wzb.eu/org2011).

Prouteau, L., and Wolff, J. (2013). Adhésions et dons aux associations: permanence et évolutions, Nantes, LEMNA WP 2012/25 (forthcoming).

Richez-Battesti, N., Petrella, F., and Melnik, E. (2011). Quelle qualité de l'emploi au sein de l'emploi de l'économi sociale et solidaire ? Premiers résultats sur données françaises in RECMA. Revue internationale de l'économie sociale, 319, 37-57.

Rosanvallon, P. (2004). Le modèle politique français. La société française contre le jacobinisme de 1789 à nos jours, Le Seuil, Paris.

Rosenski, N. (2012). Die wirtschaftliche Bedeutung des Dritten Sektors. In Statistisches Bundesamt, Wirtschaft und Statistik, März 2012, 209-217.

Sachße, C. (1995). Verein, Verband und Wohlfahrtsstaat. Entstehung und Entwicklung der dualen Wohlfahrtspflege. In T. Rauschenbach, C. Sachße, and T. Olk (eds.). Von der Wertegemeinschaft zum Dienstleistungsunternehmen, Suhrkamp Verlag, Frankfurt, 123-149. 
Sachße, C. (1996). Public and Private in German Social Welfare. In M. B. Katz, and C. Sachße (eds.). The Mixed Economy of Social Welfare, Nomos, Baden-Baden, 148-169.

Salamon, L. M. (1987). Partners in Public Service: The Scope and Theory of GovernmentNonprofit Relations. In W. W. Powell (ed.). The Nonprofit Sector. A Research Handbook, Yale Univ. Press, New Haven, 99-117.

Salamon, L. M., and Anheier, H. K. (1998). Social Origins of Civil society: Explaining the Nonprofit Sector Cross-Nationally. Voluntas, Vol. 9, No. 3, 213-248.

Strachwitz, R. G. (2010). Die Stiftung - ein Paradox?, Lucius \& Lucius, Stuttgart.

Streeck, W. (1999). Vielfalt und Interdependenz: Überlegungen zur Rolle intermediärer Organisationen in sich ändernden Umwelten. In W. Streeck (ed.). Korporatismus in Deutschland. Zwischen Nationalstaat und Europäischer Union, Campus Verlag, Frankfurt, 223-25.

Stiglitz, J., Sen, A., and Fitoussi, J. (2009). Rapport de la Commission sur la mesure de la performance économique et du progrès social, La Documentation Française, Paris.

Tchernonog, V. (2007). Le paysage associatif français. Mesures et évolution, DallozJurisassociations, Paris, 203.

Zimmer, A. (1999). Corporatism Revisited - The Legacy of History and the German Nonprofit-Sector. Voluntas, Vol. 10, No. 1, 37-49.

Zimmer, A. (2007). Zivilgesellschaft konkret: Vereine, VS Verlag, Wiesbaden.

Zimmer, A., Appel, A., Dittrich, C., Lange, C., Sitterman, B., Stallmann, F., and Kendall, J. (2009). Germany: On the social policy centrality of the Free Welfare Associations. In J. Kendall (ed.). Handbook on Third Sector Policy in Europe: Multi-Level Processes and Organised Civil Society, Edward Elgar, Aldershot, 21-42.

Zimmer, A., Basic, A., and Hallmann, T. (2011). Sport ist im Verein am schönsten? Analysen und Befunde zur Attraktivität des Sports für Ehrenamt und Mitgliedschaft. In T. Rauschenbach, and A. Zimmer (eds.). Bürgerschaftliches Engagement unter Druck? Gemeinnützige Organisationen in den Bereichen Soziales, Kultur und Sport im politischen und gesellschaftlichen Wandel, Barbara Budrich, Opladen, 269-385.

Zimmer, A., and Priller, E. (2007). Gemeinnützige Organisationen im gesellschaftlichen Wandel, VS-Verlag, Wiesbaden.

Zivis (2011). Zivilgesellschaft in Zahlen, Modul 1. Endbericht, Statistisches Bundesamt und Centrum für soziale Investitionen und Innovationen. 
Figure 1: Increase of the number of voluntary associations in Germany. 1960 - 2011

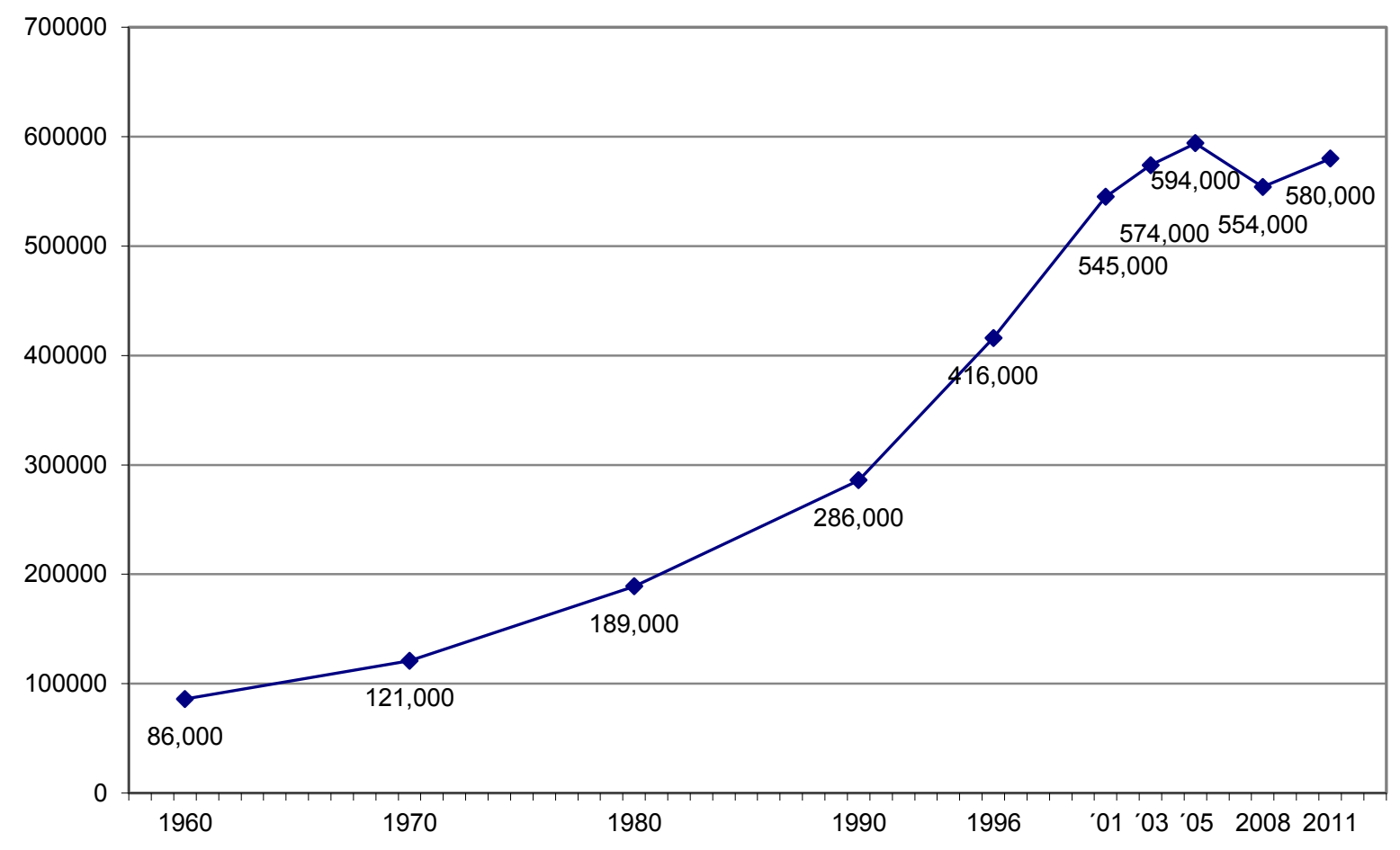

Sources: Johns Hopkins Comparative Nonprofit Sector Project; Vereinsstatistik 2001-2011: V \&M Service GmbH, Konstanz, Germany; Priller 2013 
Figure 2: Annual Foundation of Associations, 1960 - 2011

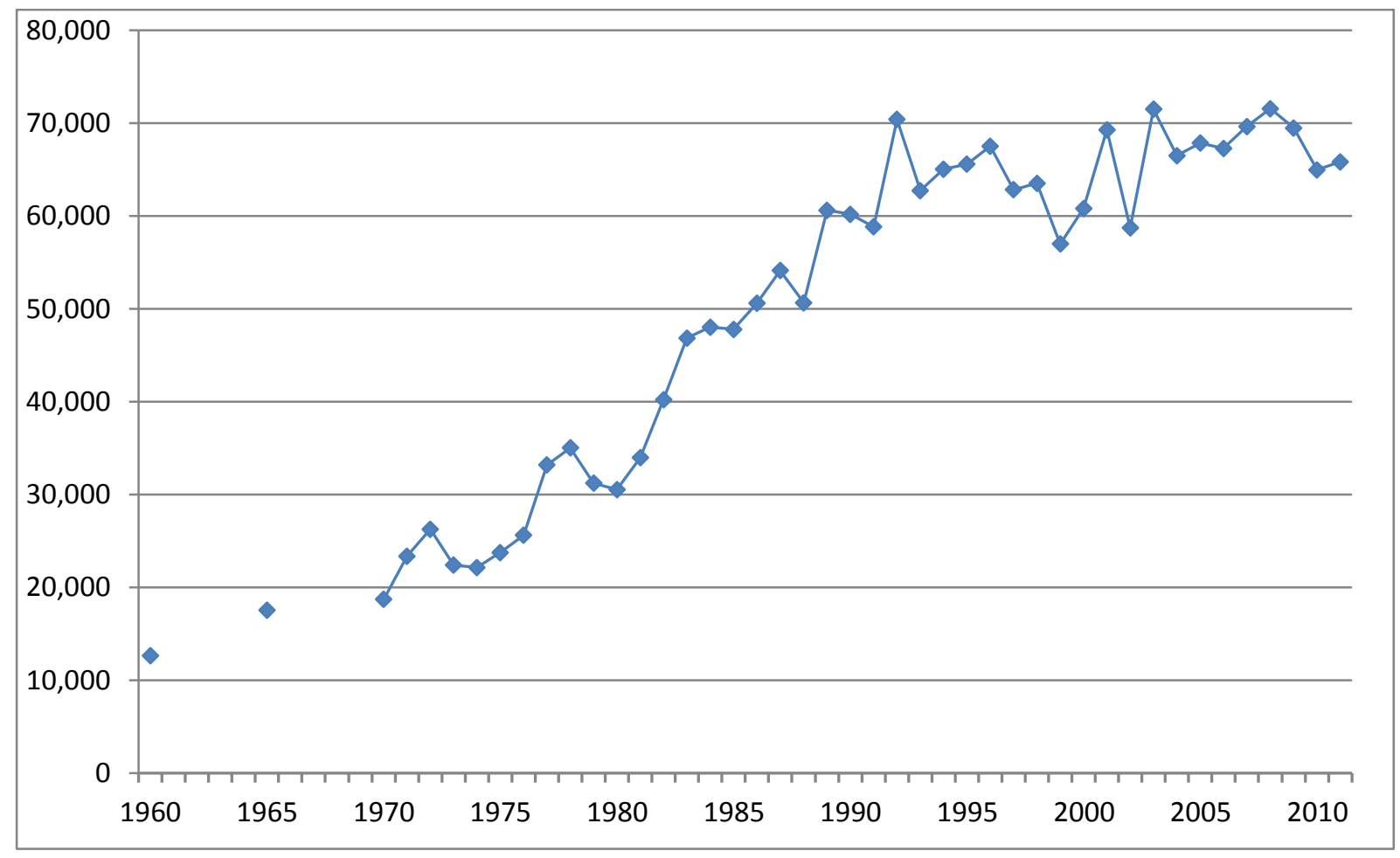

Source: Ministère de l'Intérieur, Journal officiel (except Departement Alsace-Moselle) 
Table I: Nonprofit Organizations and Nonprofit Employment by Activity, $2009^{1}$

\begin{tabular}{|l|r|r|r|r|r|}
\hline Activity field & $\begin{array}{c}\text { Nonprofit } \\
\text { Organizations }\end{array}$ & Employees & $\begin{array}{c}\text { Full-time } \\
\text { Equivalents } \\
\text { (FTE) }\end{array}$ & $\begin{array}{c}\text { \% of total } \\
\text { nonprofit } \\
\text { FTE }\end{array}$ & $\begin{array}{c}\text { \% of total } \\
\text { activity } \\
\text { field FTE }\end{array}$ \\
\hline Health & 3900 & 152000 & 127000 & $\mathbf{8 . 2 \%}$ & $\mathbf{7 . 5 \%}$ \\
\hline Social services & 32120 & 868000 & 695000 & $\mathbf{4 4 . 8 \%}$ & $\mathbf{6 0 . 3 \%}$ \\
\hline $\begin{array}{l}\text { Culture, sports and } \\
\text { recreation }\end{array}$ & 56840 & 115000 & 93000 & $\mathbf{6 . 0 \%}$ & $\mathbf{3 9 . 5 \%}$ \\
\hline $\begin{array}{l}\text { Education, training and } \\
\text { research }\end{array}$ & 21650 & 346000 & 288000 & $\mathbf{1 8 . 5 \%}$ & $\mathbf{1 7 . 5 \%}$ \\
\hline $\begin{array}{l}\text { Other: Environment, } \\
\text { Advocacy, local } \\
\text { development, housing, } \\
\text { professional and nec }\end{array}$ & 70150 & 388000 & 330000 & $\mathbf{2 1 . 2 \%}$ & \\
\hline \multicolumn{1}{|c|}{ Total } & $\mathbf{1 8 4 ~ 8 6 0}$ & $\mathbf{1 8 6 9 0 0 0}$ & $\mathbf{1 5 3 3 0 0 0}$ & $\mathbf{1 0 0 . 0 \%}$ & $\mathbf{7 . 5 \%}$ \\
\hline
\end{tabular}

Source: INSEE, Tableaux harmonisés de l'Economie sociale

\footnotetext{
${ }^{1}$ Nonprofits include associations and foundations and do not include the nonprofit establishments run by mutuals. According to an agreement between INSEE and CNCRES to define the scope of social economy it does not incude worship organizations, political parties, labor unions, and business and trade unions despite their legal status is association.
} 
Figure 3: Areas of Nonprofit Activity and Gross Value Added (in\%)2

- Health and Social Services

interest Groups

Education

- Cultur, Sport and Entertainment

Research and Developement

$\square$ Other fields

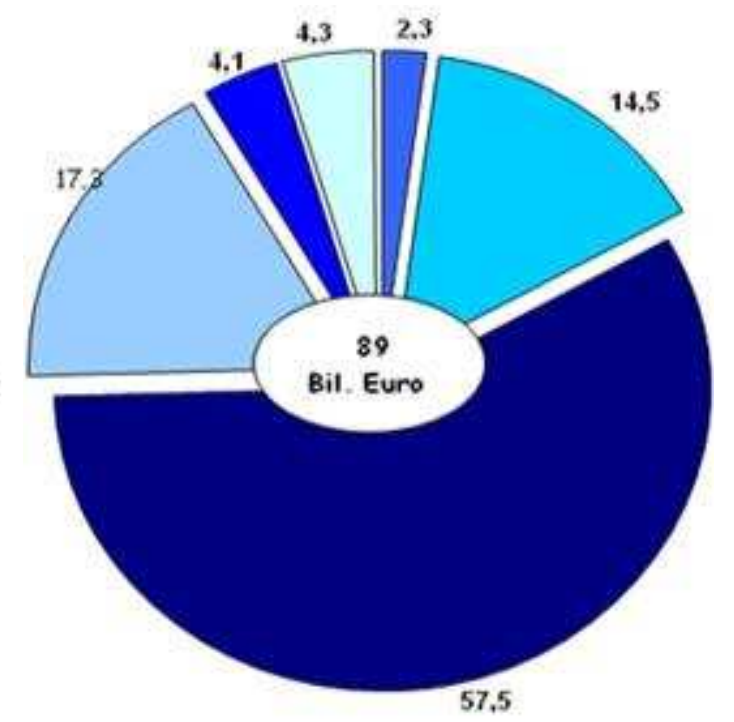

Source: Krimmer 2011: Zivilgesellschaft in Zahlen

2 Exclusively nonprofits with employees are considered. 
Table II: Organizations and Areas of Activity of the German Welfare Associations, 2008

\begin{tabular}{|l|r|r|r|}
\hline Area of Service & Organizations & Full-time Employees & Part-time Employees \\
\hline Health care & 8.462 & 222.435 & 152.451 \\
\hline Youth & 38.092 & 146.018 & 179.955 \\
\hline Family & 7.201 & 16.029 & 45.470 \\
\hline Senior citizens & 16.524 & 152.750 & 246.164 \\
\hline People with disabilities & 15.365 & 125.815 & 165.492 \\
\hline $\begin{array}{l}\text { People in special social } \\
\text { situations }\end{array}$ & 7.782 & 13.765 & 13.936 \\
\hline Others & 7.329 & 25.625 & 22.279 \\
\hline Training Facilities & 1.638 & 6.086 & $\mathbf{8 3 3 . 3 0 6}$ \\
\hline Subtotal & $\mathbf{1 0 2 . 3 9 3}$ & $\mathbf{7 0 8 . 5 2 3}$ & 4.419 \\
\hline $\begin{array}{l}\text { Self-help and community } \\
\text { service groups }\end{array}$ & 34.817 & 2.347 & 837.725 \\
\hline \multicolumn{1}{|c|}{ Grand total } & 137.210 & 710.870 & $\mathrm{BAG}$ \\
\hline
\end{tabular}

Source: $\quad$ Bundesarbeitsgemeinschaft der Freien Wohlfahrtspflege e.V. (BAGFW) (2009): Einrichtungen und Dienste der Freien Wohlfahrtspflege. Gesamtstatistik 2008 
Table III: Nonprofit Employment in Germany*

\begin{tabular}{|l|c|c|c|}
\hline & $\begin{array}{c}1990 \\
\text { (without former } \\
\text { East-Germany) }\end{array}$ & 1995 & 2007 \\
\hline Nonprofit Employees (in Mio.) & 1.3 & 2.1 & $2.3^{*}$ \\
\hline $\begin{array}{l}\text { Share of Nonprofit Employment of total } \\
\text { Employment (in \%) }\end{array}$ & 3.74 & 4.93 & 9.0 \\
\hline
\end{tabular}

* part- and full-time employment

Source: Johns Hopkins Comparative Nonprofit Sector Project \& Rosenski 2012 
Figure 4: Women, Part-time, and Temporary Employees in Germany's Labour Force, 1996 and 2008 in \%

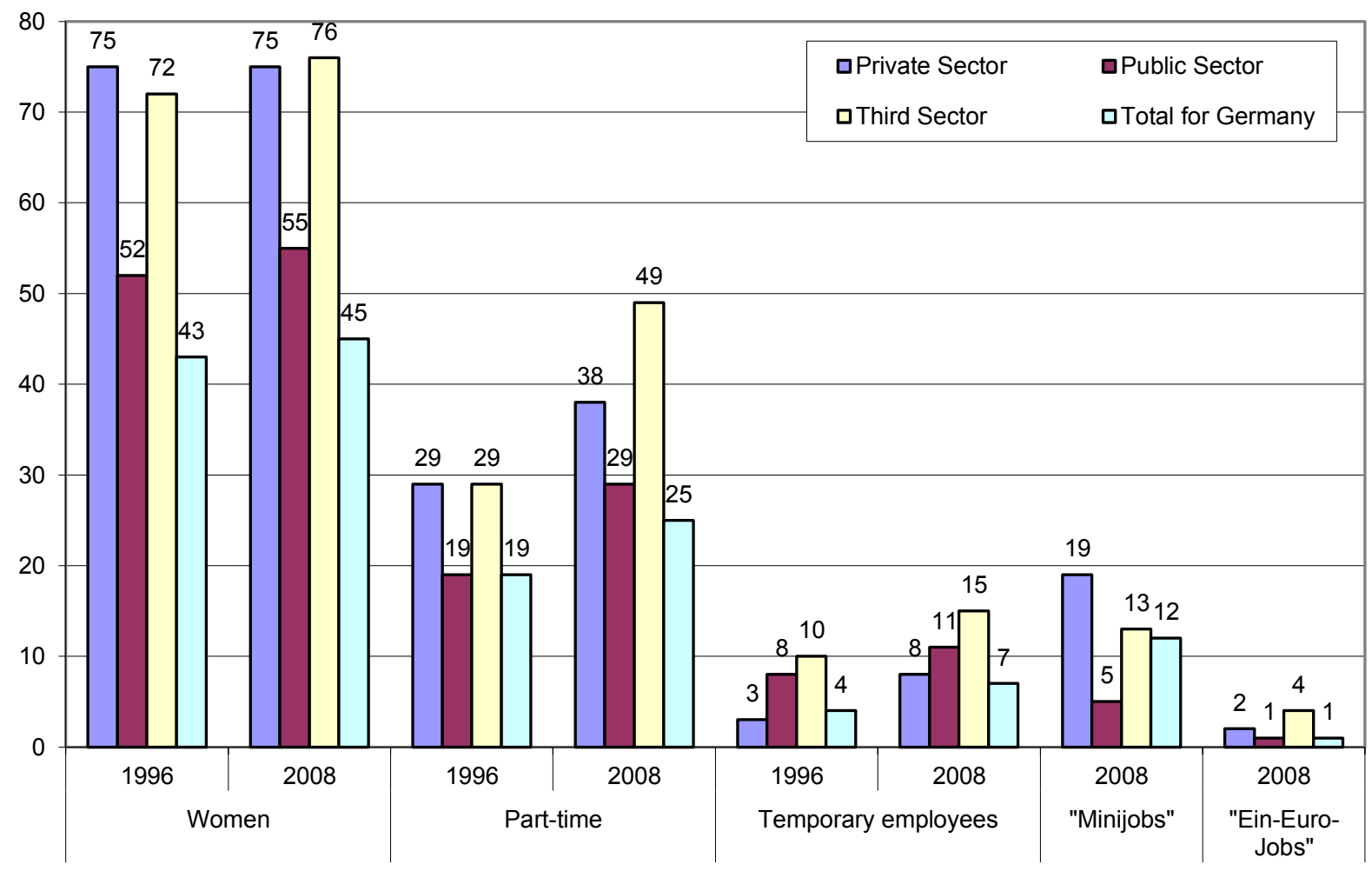

Source: $\quad$ IAB Betriebspanel, 1996-2008 
Table IV: Development of Volunteering in France, 1990 - 2010

\begin{tabular}{|l|c|c|c|c|c|}
\hline & $\mathbf{1 9 9 0}$ & $\mathbf{1 9 9 3}$ & $\mathbf{1 9 9 6}$ & $\mathbf{2 0 0 2}$ & $\mathbf{2 0 1 0}$ \\
\hline Volunteers (millions) & 7.9 & 9.0 & 10.4 & 12 & 16,1 \\
\hline $\begin{array}{l}\text { Volunteers } \\
\text { in \% of adult population }\end{array}$ & $\mathbf{1 9 \%}$ & $\mathbf{2 1 \%}$ & $\mathbf{2 3 \%}$ & $\mathbf{2 6 \%}$ & $\mathbf{3 2 \%}$ \\
\hline
\end{tabular}

Sources: France - 3 Surveys LES/ISL/JHCNP for 1990, 1993 and 1996; INSEE 2002; DREES-BVA for 2010. 
Figure 5: Development of Volunteering in Germany, 1985 - 2009

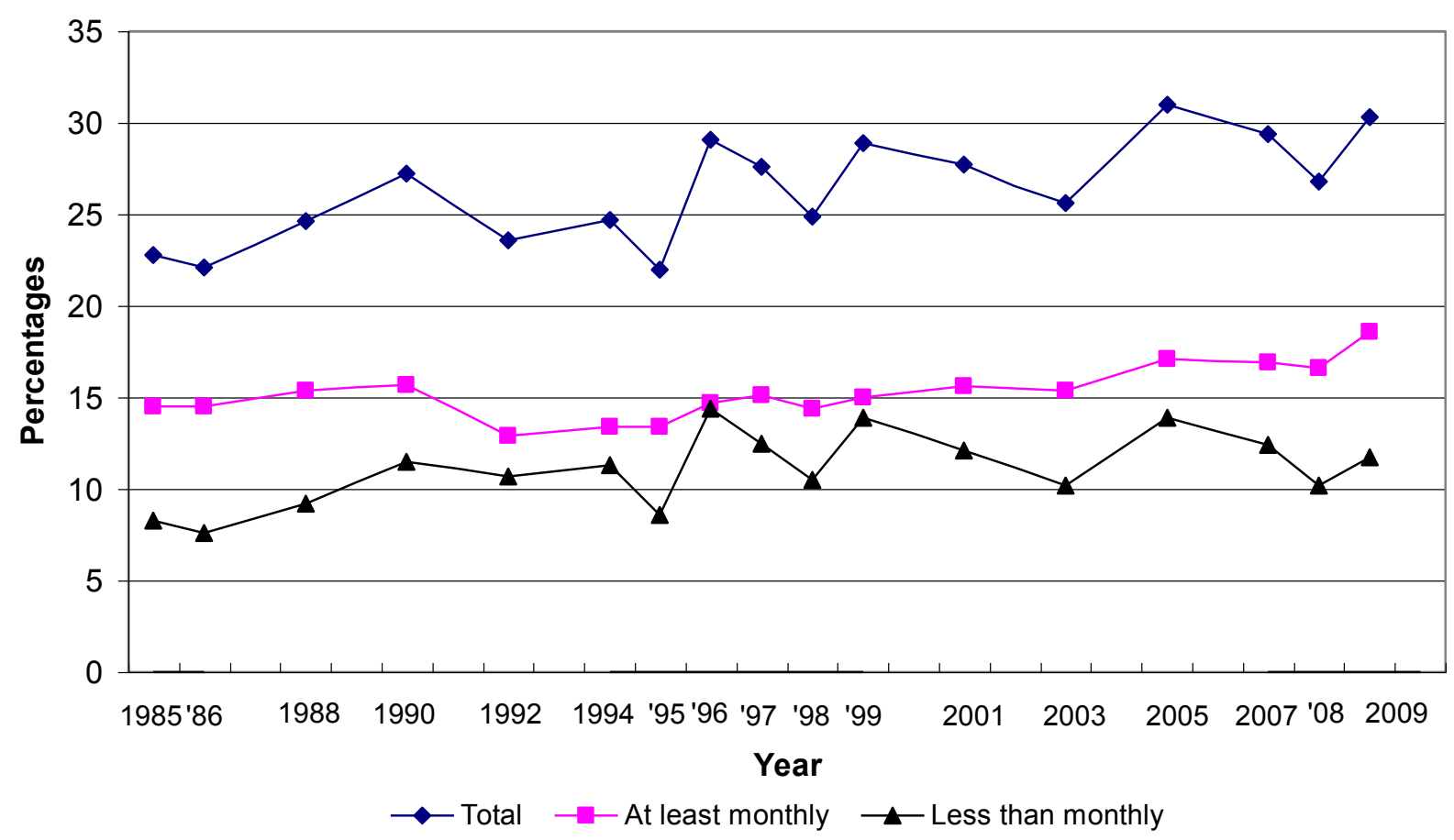

Source: Priller 2013 
Figure 6: Volunteering in Germany by Filed of Activity, 1999, 2004, and 2009, in percent of Overall Volunteering

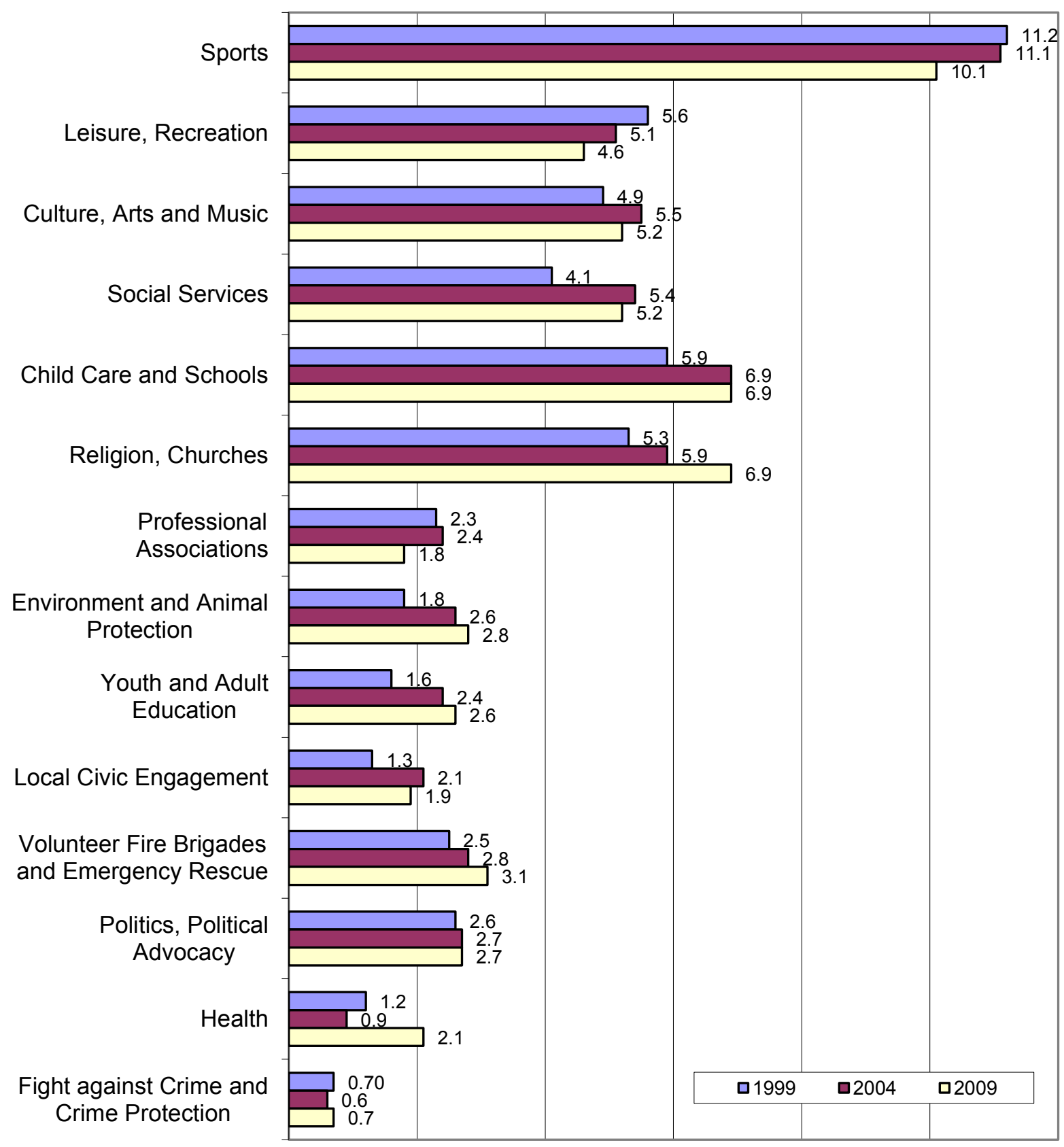

Source: Freiwilligensurvey 1999, 2004, 2009 
Table V: Volunteering in France by Fields of Activity, 2006 in \% of Total Volunteering

\begin{tabular}{|l|c|c|c|}
\hline Activities & $\begin{array}{l}\text { NPOs with } \\
\text { volunteers only }\end{array}$ & $\begin{array}{l}\text { NPOs with } \\
\text { paid employees }\end{array}$ & Total NPOs \\
\hline Sports & $28 \%$ & $33 \%$ & $\mathbf{2 9 \%}$ \\
\hline Culture & $18 \%$ & $12 \%$ & $\mathbf{1 6 \%}$ \\
\hline Social services and health & $11 \%$ & $21 \%$ & $\mathbf{1 3 \%}$ \\
\hline Leisure, recreation & $14 \%$ & $8 \%$ & $\mathbf{1 2 \%}$ \\
\hline Advocacy & $12 \%$ & $5 \%$ & $\mathbf{1 0 \%}$ \\
\hline Humanitarian charities & $9 \%$ & $12 \%$ & $\mathbf{1 0 \%}$ \\
\hline Youth and adult education & $3 \%$ & $5 \%$ & $\mathbf{4 \%}$ \\
\hline Professional and economic interests & $3 \%$ & $4 \%$ & $\mathbf{4 \%}$ \\
\hline Other & $2 \%$ & Insignificant & $\mathbf{2 \%}$ \\
\hline TOTAL & $\mathbf{1 0 0 \%}$ & $\mathbf{1 0 0 \%}$ & $\mathbf{1 0 0 \%}$ \\
\hline Volunteers & $\mathbf{7 1 2} \mathbf{6 0 0}$ & $\mathbf{2 2 2} \mathbf{8 0 0}$ & $\mathbf{9 3 5} \mathbf{4 0 0}$ \\
\hline
\end{tabular}

Source: Tchernonog 2007: Organization Survey, without religious organizations 
Figure 7: Membership Quota in Voluntary Associations (Clubs) in European Countries

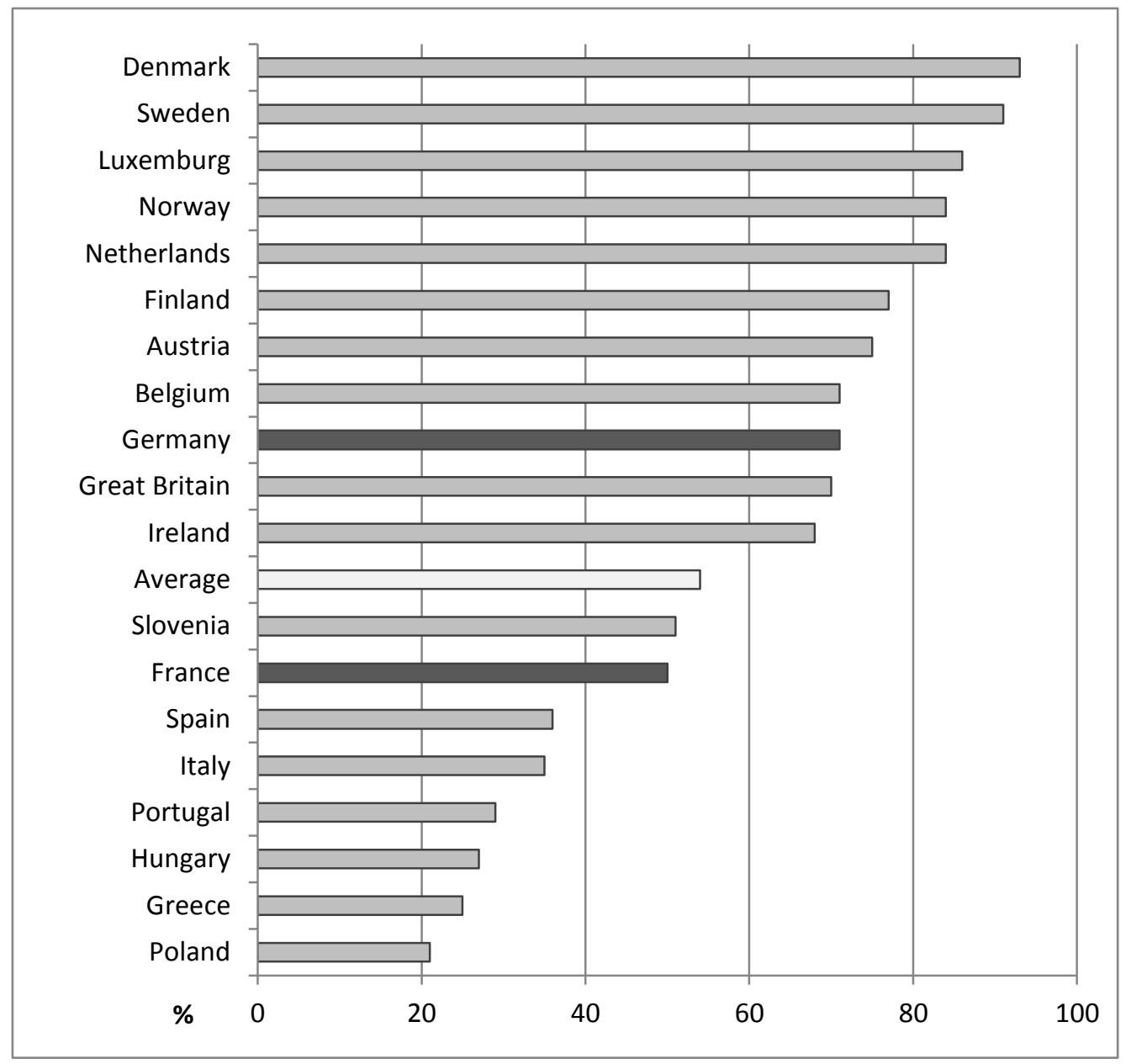

Source: European Social Survey 2002/2003; Priller 2013 
Figure 8: Quota of Donators in European Countries

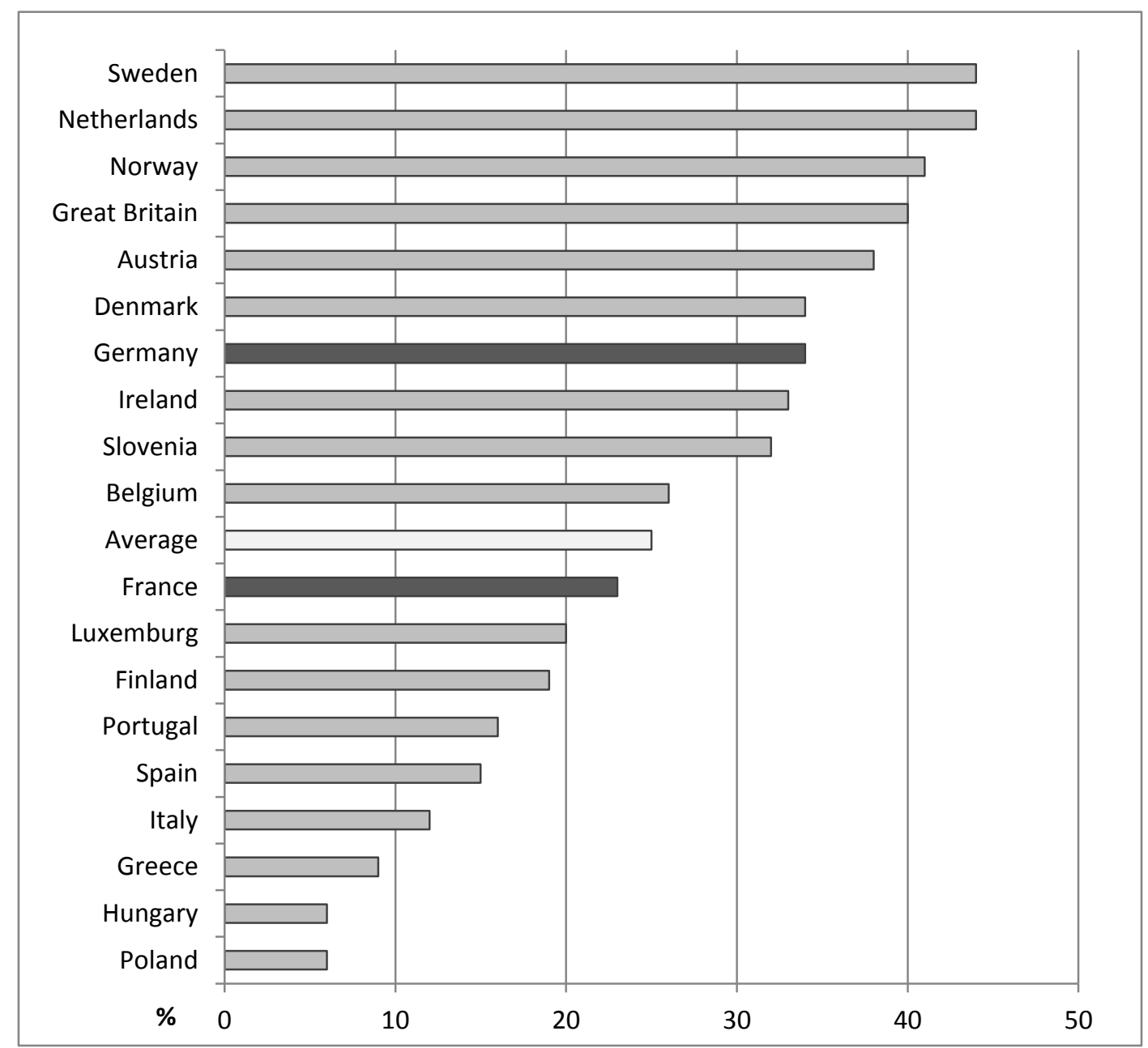

Source: European Social Survey 2002/2003; Priller 2013 
Figure 9: Number of new Foundations in Germany, 1990-2011

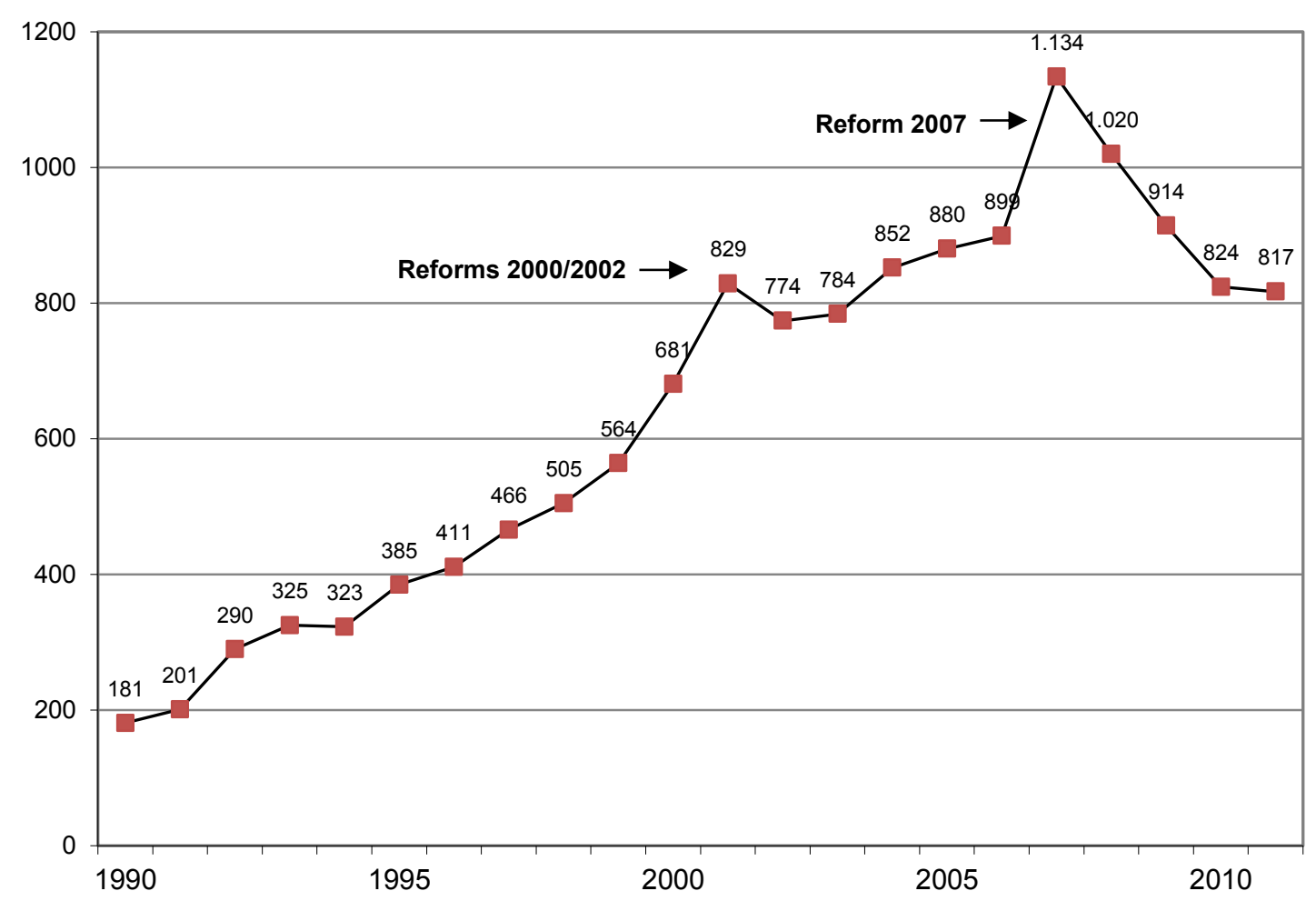

Source:Bundesverband Deutscher Stiftungen; Prilller 2013 


\begin{abstract}
According to the "social origin theory" of civil society studies (Salamon and Anheier 1998), the nonprofit sector of today constitutes a "repository of former societal struggles and conflicts". France and Germany stand for very different societal traditions, political legacies and administrative structures. Traditionally, France is a highly centralized country in which local governments do not enjoy much autonomy. In contrast, Germany is a federalized country where self-government of local communities was introduced as early as at the beginning of the $19^{\text {th }}$ century. Against this background, it comes as a surprise that, aside from few exceptions, the nonprofit sectors in the two countries are very similar. How does this come? We argue that the reason why the French nonprofit sector of today is very similar to the German nonprofit sector is closely linked to the growth of the welfare state in the two countries.
\end{abstract}

\title{
1. Introduction
}

According to the "social origin theory" of civil society studies (Salamon and Anheier 1998), the nonprofit sector of today constitutes a "repository of former societal struggles and conflicts". Correspondingly, nonprofits are embedded in administrative and organizational settings, which, in many cases, date back in history as far as to the second half of the 19th century when industrialization and urbanization began to hold sway in the western world.

France and Germany stand for very different societal traditions, political legacies and administrative structures. Traditionally, France is a highly centralized country in which local governments do not enjoy much autonomy. In contrast, Germany is a federalized country where self-government of local communities was introduced as early as at the beginning of the $19^{\text {th }}$ century. Heterogeneity in terms of religious groups, regional and cultural differences has always been a central feature of Germany. On the contrary, France has always been portrayed as a textbook-example of a catholic society, governed by a powerful administrative elite. Germany stands for a tradition of "third party government" or neo-corporatism, which translates into a government working closely together with the nonprofit sector with respect to policy formulation as well as policy implementation (Zimmer 2001). Neo-corporatism has never been a feature of the French political culture.

Against this background, it comes as a surprise that, aside from few exceptions, the nonprofit sectors in the two countries are very similar. How does this come? We argue that the reason why the French nonprofit sector of today is very similar to the German nonprofit sector is closely linked to the growth of the welfare state in the two countries. The driving force, which eradicated features of "typical German" and "typical French" of policy implementation, was the aim of both government to provide citizens with a broad spectrum of social services. However, faced with significant fiscal constrains, a slow down of the economy, and a worldwide paradigmatic shift in welfare state policies, since the 1990s, German governments have already significantly changed their attitude towards the sector. Most recent 
developments in France and in Germany, therefore, give way to the question whether the success story of nonprofits in the neighboring countries might come to an end.

The following paper firstly provides an historical overview of the traditions of nonprofit embeddedness in France and Germany. It also focuses on the topic of how governments in France and Germany have made use of the sector traditionally, and during the heyday of the welfare state. Secondly, a comparative statistical portrait of the sector in the two countries uncovers striking similarities. But, it also shows that there are still at least some differences. The concluding chapter addresses the topic of how government - nonprofit relations will further develop in the two countries.

\section{Developments and State of the Art of the Nonprofit Sector in France and Germany}

\subsection{State-Nonprofit Relationships in the $19^{\text {th }}$ Century: Aloofness in France - Embracement in Germany}

Statism, state control and centralization, are the most important features and long-term trends in French history. The millennium fight of the central state against any form of local power is at the root of French centralization. French kings fought against feudal order and against urban citizens' organizations during the Middle Ages; they fought against regional governments and religious minorities such as Protestants and Jews during the $17^{\text {th }}$ and $18^{\text {th }}$ centuries. Furthermore, French staatehood is based on the notion of a direct and close interrelation between the state and its citizens. In accordance with both the political philosophy of Jean Jacques Rousseau and the ideas of the French Revolution, intermediaries such as guilds, fraternities or any kind of voluntary association were supposed to be in the way and hence counterproductive with respect to modern polity and society. This very notion of statehood was enshrined in the famous Loi le Chapelier of 1791: "No one shall be allowed to arouse in any citizen any kind of intermediate interest and to separate him from the public weal through the medium of so-called common interests" (Archambault 1997: 28; Rosanvallon, 2004).

During the $19^{\text {th }}$ century, liberal legislation tended to loosen the reins on intermediaries, such as mutual societies, trade unions or business associations. However throughout the century, the successive monarchs and republics in France kept a critical eye on any societal movement or organization that did not belong to the realm of the state, such as the labour movement, the Catholic Church or political clubs. Finally, we have to keep in mind that worldwide the development of a nonprofit sector and the rapid growth of voluntary associations was a byproduct of industrialization and urbanization in the $19^{\text {th }}$ century. At that time associations were an urban phenomenon. However, it might be questioned whether the concept of 
"industrial revolution" that translates into rapid demographic growth, urbanization and a decreasing economic significance of agriculture can be applied to France which in the second half of the $19^{\text {th }}$ century and the first half of $20^{\text {th }}$ century was still a rural nation with only a few industrial and densely populated cities or metropolis (Archambault 1997: 30; Archambault 2001).

Compared to France, German government - nonprofit relationships were very different in the $19^{\text {th }}$ century. With the introduction of self-government at the local level in Prussia, German governments started to work with nonprofits by using them as tools of public policy. Faced with the risk of bankruptcy after the Napoleon Wars, the Prussian State, the largest among the German kingdoms and serfdoms, started a remarkable administrative reform that among other issues introduced the concept of local self-government. Responsibility for local affairs in terms of societal and political matters, finances included, was handed over to the local communities. Berlin was no longer responsible for the financing of local welfare; by way of reciprocation, Berlin also gave up the right to interfere directly in local affairs (Bogumil/Holtkamp 2006). From the very beginning of self-government, due to the lack of resources, local governments had to co-operate with local charities, nonprofit organizations or social entrepreneurs (Sachße 1995; Zimmer et al 2009). The Prussian approach towards selfgovernment at the local level set a precedent that was copied, albeit with stark regional and local modification, throughout Germany in the $19^{\text {th }}$ century. Although a strong state or etatism also constitutes a central feature of German tradition, "intermediaries" such as guilds and fraternities, nonprofit organizations and voluntary associations were not per se perceived as if they were posing a thread to the modernizing state in the $19^{\text {th }}$ century. On the contrary, in Germany, parts of the emerging nonprofit sector were smoothly and very successfully integrated into modernizing strategies which were started, monitored and supervised by the state and its growing administration. Germany's nonprofit sector in the $19^{\text {th }}$ century constitutes a prime example for a sector which developed and flourished "under the thump" of a state. The sector provided room for numerous initiatives, and a "private culture of welfare" (Sachße 1996) without endangering state authority.

The reason why a lively nonprofit sector operated successfully in an authoritarian regime is closely linked to the ideas of the political philosophy of Friedrich Hegel. According to his logic and in sharp contrast to the ideas of the French Revolution, Hegel differentiated between the realm of the state and society. While the State is responsible for the common good, civil society or bürgerliche Gesellschaft constitutes the space where citizens through Korporationen and hence membership organizations are able and allowed to follow their specific interests. However, the state guarantees that "private interests" are not getting out of hand. Hegel promoted the concept of a strong state and a strong civil society. But the Hegelian civil society operates under the tutelage of the state. Having this concept in mind, it 
follows logically that an integration of nonprofit organizations into state initiated and supervised policies does not put a threat to state authority. On the contrary, working closely with nonprofits supports the advancement of state authority because it provides government initiatives with legitimacy.

\subsection{State -Nonprofit Relationships in the Period of Welfare State Expansion: France Following the German Model}

Against this background, the German tradition of neo-corporatism which traditionally assigned societal bodies, such as trade unions, business associations and nonprofit charities, specifically the German Welfare Associations as well as the umbrella associations of sports clubs and other societal and leisure activities, an important role in the policy process (Streeck 1999, Lembruch 1996, Katzenstein 1987) becomes understandable. Without going into detail, the originally local approach of third party government (Salamon 1987) and hence policy making in close co-operation with (policy-formulation) as well as through (policy implementation) nonprofit organizations has been upgraded to the national level in Germany as early as in the late $19^{\text {th }}$ beginning of the $20^{\text {th }}$ century. What modern political scientists title neo-corporatism - governing with the assistance of associations at any level of government and in a broad spectrum of policy fields - looks back upon a long tradition in Germany.

During the period of welfare state expansion, Germany, in accordance with path-dependency, strongly built on the country's tradition of a close partnership between government and nonprofit organizations, in particular in the core welfare arena but also in other policy fields such as leisure or sports. In the aftermath or World War II, neo-corporatism which some political scientists also title meso-corporatism developed into the overall strategy of policy making in Germany. At the national level of government, policy field specific umbrella organizations, such as the Welfare Associations or the German Olympic Sports Association, were and still are thoroughly integrated into the policy process. At the Federal and regional level, representatives of the "umbrellas" work on par with representatives of government administration and politicians. At the local level, the membership organizations of the umbrellas, hence the local sport clubs or the organizations and institutions of the Welfare Associations, are thoroughly integrated into the process of policy implementation. Funding is safeguarded and regulated by the Federal Government in the core welfare domain; funding for leisure and sports belongs to the responsibility of local governments and hence depends on their specific financial liquidity.

The German version of "third party government" translated into a remarkable success story of the nonprofit sector in the core welfare domain as well as in the area of sports and leisure. The German Welfare Associations developed into the most important providers of social services next to public entities in Germany. Also the success story of the German sport clubs is 
outstanding. There are more than 95.000 sports clubs being active in Germany (Zimmer et al 2011). The core of the "German model" encompasses decentralized service provision as a joint endeavour of public-nonprofit cooperation and centralized policy formulation with the aim of providing a framework for policy enactment without going into details and hence granting communities and regions some leeway for manoeuvring.

To a certain extent, the German model at least influenced the French approach towards the nonprofit sector and its organizations. At the beginning of the $20^{\text {th }}$ century (1901) the freedom of association was safeguarded legally in France. However, the development of the sector, its significant growth and flourishing went hand in hand with the build-up and expansion of the welfare state in France, which started in the aftermath of the Second World War and particularly since the 1960 s.

From this decade onward, there is a trend in France of less state control and more attention has been paid to the tradition of most European continental countries. The first Decentralization Act (1983) is a way to strive towards a more European political structure. In France, decentralization is recent but it seems to have been a strong incentive to the nonprofit sector development. Reducing the prerogatives of the central government to the benefit of regions, departments and local communities, decentralization has given way to a new kind of partnership between nonprofit organizations and local authorities.

In other words, instead of neglecting or even oppressing private nonprofit initiatives, French governments increasingly started to co-operate with the sector and its organizations. Step by step, the areas of co-operation were expanded. In the 1950s, nonprofits supporting physically or mentally handicapped citizens and social tourism associations running holiday resorts, were acknowledged by the government as legitimate providers of services. In the 1960s, nonprofits enhancing the democratization of sports and culture were encouraged and supported by the government as well as multipurpose associations disseminating popular culture. In the 1980s and 1990s with significant government support, many nonprofits were created to cope with social exclusion by providing work to unemployed citizens. Moreover, against this benevolent background, fine examples of social entrepreneurship came to the fore in France. A case in point is the organization Medecins sans frontieres, the famous "French doctors", which were awarded the Peace Nobel Price. Most recently, government support through tax incentives and subsidies gave rise to the foundation of many home care services and other facilities for an aging society that are provided and managed mainly by nonprofits.

The embracement of the sector by the welfare state resulted in both countries into a success story and remarkable growth. In France and in Germany, the today's nonprofit sector constitutes a highly integrated component of each country's welfare state. Alongside with the 
growing importance of social policy and particularly social service provision, nonprofit organizations developed into important tools of political engineering. The following statistical portrait of the two sectors reveals a picture of striking similarity.

\section{Statistical Profile of the Nonprofit Sectors in France and Germany 3.1 Nonprofit Growth in France and Germany}

A common feature of the sector in both countries is its remarkable growth, particularly since the mid 1970. In quantitative terms, nonprofit organizations in France and Germany look back upon a success story of accelerated growth that translated into a foundation boom of nonprofit organizations.

Figure 1: Increase of the number of voluntary associations in Germany. 1960 - 2011

Sources: Johns Hopkins Comparative Nonprofit Sector Project, 2001-2011: V\&M Service $\mathrm{GmbH}$, Konstanz, Germany; Priller 2012, in press

In Germany, the majority of nonprofits are legally "chartered associations" (eingetragene Vereine). According to the results of the Hopkins Project, the number of these associations has more than sextupled from 86.000 in 1960 (former West Germany only) to over 550.000 in 2008 and 580.000 in 2011. This "associational boom" outmatched the growth rates of both public entities and for-profit companies (Zimmer/Priller 2007: 55). Although there are many nonprofit organizations in Germany, as local studies clearly show (Zimmer 2007) that are dating back to the early $19^{\text {th }}$ century, the vast majority of German nonprofits has been founded during the last four decades in former West-Germany, and during the last twenty years in former East-Germany and it is the same in France (Tchernonog, 2007).

The same success story of nonprofit growth took place in neighboring France during the last decades. Again, "association" constitutes the generic legal form of the majority of French nonprofits. Starting in the late 1970s, between 60.000 to 70.000 associations were newly founded per year, more than three times the average of the 1960s.

Figure 2: Annual Foundation of Associations, 1960 - 2011

Source: Ministère de l'Intérieur, Journal officiel (except Departement Alsace-Moselle)

Today, there are 1.200.000 associations operating in France. The vast majority - similar to Germany - are small and locally active organizations, which are working either exclusively 
with volunteers of with very few paid employees. All in all, there are just 160.000 associations managed by professional staff; 2.000 associations have been granted by the French government the "Reconnue d'Utlité Publique", a special legal form that guarantees the full legal capacity.

\subsection{Integration into the Welfare State}

Nonprofit social service providers are in both countries the strongholds of the sector in terms of economic activity and nonprofit employment. In France, the majority of nonprofit employees are working in organizations, which are active in the core welfare related areas, in particular in social services, education and health.

Table 1: Nonprofit Organizations and Nonprofit Employment by Activity, $2009^{1}$

Source: INSEE, Tableaux harmonisés de l' Economie sociale

Every second employee who works in the French nonprofit sector is affiliated with a nonprofit, active in the area of social services. $60 \%$ of the workforce in this core area of welfare service provision is employed by a nonprofit organization in France. Nonprofit employment in the areas of health and education, which in France constitutes a public domain, is comparatively much less pronounced than in the area of social service. But also in these core welfare fields nonprofit employment is still significant.

The same holds true for Germany. Again the core welfare domain constitutes the stronghold of economic activity and employment of the German nonprofit sector. According to the most recent study of the German nonprofit sector, the areas of health and social services count for more than two thirds of the gross value of nonprofit activity in Germany.

Figure 3: Areas of Nonprofit Activity and Gross Value Added (in\%)

Source: Krimmer 2011: Zivilgesellschaft in Zahlen. Exclusively nonprofits with employees are considered.

\footnotetext{
${ }^{1}$ Nonprofits include associations and foundations and do not include the nonprofit establishments run by mutuals. According to an agreement between INSEE and CNCRES to define the scope of social economy it does not include worship organizations, political parties, labor unions, and business and trade unions despite their legal status is association.
} 
Indeed, the similarity between Germany and France with respect to nonprofit employment is striking. In Germany, nonprofit employment is concentrated in the social service domain. According to the results of the Johns Hopkins Project, the area of health and social services absorb about $60 \%$ of the sector's workforce with social services getting ahead of the area of health. Similar to the U.S., German NPO-hospitals once used to be the stronghold of nonprofit employment (Zimmer/Priller 2007: 57). However, the for-profit sector has made significant inroads into this traditional area of nonprofit activity during the last decades in Germany (Henriksen et al 2012). Currently, the nonprofit sector counts for $76 \%$ of total employment in the area of social services (Sozialwesen). In the field of health, $25 \%$ of the labor force is employed by nonprofits. The share of nonprofits in the fields of leisure and sports stand for $31 \%$ of total employment in theses areas (Priller 2012).

The vast majority of employees working in the area of health and social services in Germany are employed by a membership organization of the famous German Welfare Associations. The Associations are key players in the German welfare state with a special focus on social service provision. They are "umbrellas" with - as indicated in Table 2 - thousands of affiliated or membership organizations operating locally. The Associations - Caritas, Diaconia, German Red Cross, Parity, Workers Welfare Associations/AWO - were founded at the end of the $19^{\text {th }}$ century. Still today they are organized along normative lines and affiliated with the Churches (Caritas and Diaconia), the German Social Democratic Party (AWO) or the conservative/liberal spectrum (Red Cross) (Boeßenecker 2006).

Table 2: Organizations and Areas of Activity of the German Welfare Associations, 2008

Source: Bundesarbeitsgemeinschaft der Freien Wohlfahrtspflege e.V. (BAGFW) (2009). Einrichtungen und Dienste der Freien Wohlfahrtspflege. Gesamtstatistik 2008.

The Welfare Associations look back upon a remarkable story of growth that started in the late 1960s. The biggest players of the German Welfare Associations are Caritas and Diaconia, which are both affiliated with the two Churches. The same holds true more or less for the French functional equivalents, the private charities of which the most important ones are federated in UNIOPSS that used to be under a catholic inspiration but vanishing with the more secular French society, the less religious nowadays in Europe (Bode 2003). Hence, similar to the German situation, also in France charities, related are incorporated into the expanding welfare state when social services developed into a major area of public welfare activity in the late 1960s and early 1970s in Europe.

In both countries, the workforce of the sector is highly concentrated. The "biggest nonprofit employers" in France and in Germany are hospitals and residential caring homes. In France, the top $2 \%$ of the large organizations that employ at least 100 employees count for more than 
half of the wage bill of the nonprofit sector which amounts to 37 billion of gross wages, or $5 \%$ of the total wage bill of the private and public sector. Similar to Germany, these large French nonprofits are hospitals, nursing homes and residential facilities for the disabled that are by and large affiliated with the big humanitarian NPOs such as the French Red Cross, the Secours Catholique-Caritas or Association des Paralysés de France. According to the results of the most recent study, two thirds of the German nonprofit employment is concentrated in the areas of health care (hospitals) and social services (retirement, residental or community homes) (Zivis 2011: 65) and it is similar in France (Tchernonog 2007).

In terms of employment, the German nonprofit sector looks back upon a success story of continuous growth. According to the Johns Hopkins Project nonprofit employment has more than doubled since the early 1990s. But, compared to the 1990s, the growth rate of nonprofit employment has slowed down in the last decade. We might face a further slowing down of nonprofit employment in Germany due to both fiscal constrains and increasing competition of for-profit competitors in core nonprofit areas, such as health care.

Table 3: Nonprofit Employment in Germany

Source: Johns Hopkins Comparative Project \& Rosenski 2012

\subsection{Feminized Labor Force Working in "Odd Jobs"}

Since in both countries, nonprofit organizations, working with professional staff are primarily active in the service industry, the majority of the sector's work force in France and Germany are women. In France $69 \%$ of the sector's workforce are women, in Germany $76 \%$ of the sector's employees are female (Priller 2012). The trend towards an increasingly feminized nonprofit labor force goes hand in hand with a deterioration of the quality of jobs in the sector. The reasons for this development are closely related to a change of welfare policies. Instead of working exclusively with nonprofits, in France and Germany, government increasingly tends to enhance competition between nonprofit and for-profit providers of health and social services. The outcome on increased competition at the level of the organizations translates into a significant increase in part-time employment and a proliferation of temporary employment relationships.

Figure 4: Women, part-time, and temporary employees in Germany's labor force, 1996 and 2008 in \%

Source: IAB Establishment Panel, 1996-2008.

The poor quality of employment in NPOs constitutes a further common feature of the French and German nonprofit sectors. In both countries, the percentage of part-time, seasonal and 
other forms of "odds" or flexible jobs is higher than in the other sectors. Furthermore, NPOs welcome the greatest part of the so-called "helped jobs" or government subsidized jobs which are created to cope with problems caused by structural unemployment of specific groups such as young people in France or long-term unemployed in Germany. The results of most recent studies in Germany show that the quality of employment in the sector is steadily declining. Compared to the public and the for-profit sector, nonprofit organizations hold the largest share of part-time and temporary jobs Germany. Again, the labor force, employed in these unfavorable jobs, is predominately female (Priller 2012, Tchernonog 2007).

\subsection{Finances}

The French and the German nonprofit sector are both highly dependent on public money or at least publicly regulated income. The reason why public money plays such an important role for nonprofits in both countries has to do with the integration of the sector and more specifically of NPOs, active in welfare related fields, into the countries' systems of social service provision.

In France, nonprofits working with professional staff are predominately publicly funded. Up to $56 \%$ of their income comes from public sources, precisely from the national government, departements (101), municipalities (36000), and social security. NPOs, whose work force are volunteers, are far less dependent on public money, which by and large amounts to $26 \%$ or one fourth of their income. Whatever form of public funding is used, such as subsidies, contracts, or competitive bids, public money by and large goes to those NPOs that are active in the core welfare areas, precisely in the areas of education, health and social services.

Market income in terms of fees for services and dues count for $40 \%$ of the total income of professionalized NPOs working with employees. The share is even larger for nonprofessionalized NPOs that work exclusively with volunteers. $50 \%$ of their finances are market income. Locally active small NPOs and grassroots organizations also receive public support, primarily from the local authorities. However, in contrast to the large professionalized organizations, local French nonprofits, active in the areas of leisure, sports or recreational activities do no primarily live on public money. (Tchernonog 2007).

Figure 5: Revenue sources by subsector, 1995 France

Source: Johns Hopkins Nonprofit Sector Comparative Project - Phase 2

In France, the importance of private money in terms of philanthropy or donations as well as support from companies - corporate citizenship programs and sponsorship - for the finances of the sector amounts to just five \% of total income. There are also in France some large charities that are funded mainly by donations (Secours Populaire, Restaurants du Coeur, Médecins sans Frontières, Médecins du Monde). However, for the overall picture private 
funding constitutes a rather symbolic resource for nonprofits in France (Archambault et al 2010).

A split between highly professionalized nonprofits and NPOs that work almost exclusively with volunteers also characterizes the German nonprofit sector. The professionalized German NPOs are thoroughly integrated into the country's welfare state. Working in the areas of health and social services, they are predominately public funded. On the contrary, the vast majority of small nonprofits, active in the areas of leisure and sports work predominately with volunteers. They also receive small public subsidies, predominately from local governments as well as infrastructural support in terms of facilities (e.g. sports hall, playing fields). But their prime sources of finance are membership dues.

Figure 6: Revenues of Nonprofit Organizations in 1995 (in percent), Germany

Source: Johns Hopkins Comparative Nonprofit Sector Project

In Germany, the largest share of nonprofit funding consists of payments by government entities (e.g. municipalities) or social and health insurances for services. The second most important funding source translates into public support in form of subsidies and temporary grants. Earned income - particularly membership dues - has always played an important role, particularly for those organizations that work in fields, such as sports or leisure. Similar to France, philanthropy and income from sponsorship of corporations does not play an important role for the finances of German nonprofit organization (Zimmer/Priller 2007: 81). However, there are selected organizations, such as Greenpeace Germany, that live thoroughly from donations and earned income, or which rely heavily on donations, such as the NPOs, active in humanitarian aid activities (Caritas International, Oxfam Germany).

\subsection{On the Advance: Volunteering}

Finally, volunteering as a major resource for nonprofit organizations plays out quite similar in France and Germany. But, volunteering is by no means restricted to nonprofits. Increasingly volunteer input is also of significant importance for the wellbeing of public organizations, such as schools, kindergartens or museums. Volunteering has developed positively during the last decades in both countries. However, while Germany looks back upon a stable but comparatively moderate increase in volunteering. In France, volunteering has become very fashionable in the last twenty years. Indeed, the numbers of volunteers doubled since the early 1990s in France: partly due to the fact that people who saw themselves as helping or militating say now that they are volunteering and partly to a true increase of time giving.

Table 4: Development of Volunteering in France, 1990 - 2010 
Sources: France - 3 Surveys LES/ISL/JHCNP for 1990, 1993 and 1996; INSEE 2002; DREES-BVA for 2010.

Figure 7: Development of Volunteering in Germany, 1985 - 2009

Source: Priller 2012: forthcoming

Depending on the approach and method of surveying, response rates slightly differ in Germany. According to the results and data of the German Socioeconomic Panel (SOEP), the share of persons engaged in volunteer activities has positively developed from $22.6 \%$ in 1985 to $30.3 \%$ in 2009 (see Fig. 7). Particularly, regular and very stable engagement that takes place at least once a month has been on the increase in Germany and France (Prouteau and Wolff, forthcoming). The results of the German Freiwilligensurvey reveal an even more positive picture of Germany as an active civil society. According to the Freiwilligensurvey, $36 \%$ of the German population volunteers regularly. Hence all in all, more than every third inhabitant of either France or Germany and therefore more than one third of the total population of the two neighboring countries is regularly engaged in volunteer activities.

It does not come as a surprise that the areas of volunteer activities are also very similar in France and Germany. Prime areas of volunteer activity are sports, leisure and hobby activities as well as culture and recreation. Next to these leisure related activities, volunteers are engaged in social as well as in church related areas in Germany. Definitely less frequently, Germans are less engaged in areas related to politics, advocacy or community affairs.

Figure 8: Volunteering in Germany According to Fields of Activity, 1999, 2004, and 2009, in percent of overall volunteering

Source: Freiwilligensurvey

France mirrors Germany with respect to the preferred fields of volunteer activity. The French population is engaged in sports (23\%), culture (15\%), leisure and recreation (15\%). Compared to Germany, advocacy organizations attract more volunteers (16\%) in France, while the areas of health and social services $\left(10 \%^{2}\right)$ as well as education and training $(8 \%)$, and religion $(5 \%)$ are more popular fields of volunteer activity in Germany than in France. In Germany and in France, volunteering is still highly gendered. Men who volunteer prefer sports and

\footnotetext{
${ }^{2}$ This classification deals with the members of associations that work also voluntarily for them. But lots of volunteers are not members of the organisation and these volunteers were not classified in the DREES-BVA survey.
} 
professional associations as their prime field of activity. Women are first and foremost engaged in the areas of health, social services, and education. In contrast to France, German women volunteer very often in church or religious affiliated organizations and activities.

\subsection{Legacies of History}

Despite the similarities, there are at least two aspects that are different in France and Germany. Each of those is closely linked to the political culture and tradition of the respective country. The first one has to do with Germany's tradition as a "nation of joiners". There is a significant gap between memberships quotas in France and Germany according to the results of the European Social Survey. Although almost every second citizen in France was a member of an association, the Germans surpassed the French by 20\% in 2002/2003. $70 \%$ of the Germans interviewed, were members of at least one association. But multiple membership is very frequent in Germany (Zimmer 2007).

Figure 9: Membership Quota in Voluntary Associations (Clubs) in European Countries

Source: ESS 2002/2003

There are many jokes about the German Vereinsmeierei, the tendency to found voluntary associations or clubs, based on membership for any purpose you might think of (Zimmer 2007). Some of these clubs are very old dating back to the early $19^{\text {th }}$ century, such as Reading Societies or Literary Salons; some of them were founded in the second half of the $19^{\text {th }}$ century, such as singing or sport clubs. Some of them are a product of the late $19^{\text {th }}$ and early $20^{\text {th }}$ century e.g. the gardening societies or local church affiliated charities, which were the for-runners of the German Welfare Associations, the most important providers of social services today (see Tab. 2). Membership is at the core of these nonprofit organizations. And although membership in nonprofits is slightly on the decline in Germany, there are still definitely more Germans than French members of nonprofits, respectively of clubs or membership based voluntary associations.

Furthermore, the sectors of the two countries differ with respect to private giving, the funding of foundations respectively. According to the result of the European Social Survey, Germans tend to be more engaged in private philanthropy than the French. Every third of the Germans interviewed donated on a regular basis, while in France, every fifth interviewed indicated that private philanthropy is a part of his or her life-style.

Figure 10: Quota of Donators in European Countries

Source: ESS 2002/2003 
Finally, the difference between France and Germany is impressive with respect to foundations. Again, private philanthropy was a prominent and central feature of modernizing Germany in the late $19^{\text {th }}$ century. At that time, many private foundations that were modelled after the American example were founded in Germany, in particular in the big cities like Hamburg, Berlin or Frankfurt. Depending on the region, these foundations, however, worked also closely together with public administration or government. Therefore, foundations in Germany did no perceive themselves per se as a counterbalancing force vis a vis state power. On the contrary, in many cases, private foundations and local governments share a tradition of working hand in hand with the aim of helping the poor, supporting the arts or institutions of higher education or research. During the German Empire, the establishment of foundations enjoyed government support and was perceived as being highly beneficial for the advancement of various segments of German society (Frey 1999). Accordingly, there were many private foundation operating in Germany in the late $19^{\text {th }}$ century, and hence before political and economical turmoil hold sway in the country with the effect of destroying a rich sector of foundations.

After the Second World War, it took time to catch up. But, in the meantime, Germany has developed into a vivid arena for foundations. With respect to the numbers of foundations, today Germany comes next to the U.S. There are only about 2.000 foundations operating in France, the number of foundations in Germany amounts to about 20.000 (Alscher et al 2009). The growth of the foundation sector has been heavily supported by the German government that in the 2000s, inaugurated laws which are beneficial and very supportive for private philanthropy (Alscher et al 2009).

Figure 11: New Foundations in Germany, 1990-2011

Source: Priller 2012

Summarizing the results of the statistical profile of the nonprofit sectors in France and Germany, the similarities are impressive. Alongside the growth of the welfare state, "typically French" has shifted towards "typically German". German governments have always made use of "the sector". French governments discovered the sector as a vehicle for public policy more recently. With the two exceptions of firstly foundations that in contrast to France are numerous and flourishing in Germany, and secondly membership affiliation which is at the core of political culture in Germany but less common in France, the German and the French nonprofit sector all in all are very similar. Is this also the case with respect to the topic of how 
current developments, in particular changing government policies and the fiscal crisis, have an impact on the sector in the two countries?

\section{Current Developments}

Nonprofits in France and Germany are currently confronted with similar problems and difficulties. Competition constitutes a major issue for the sector and its organizations in both countries. Due to the significant dependence of nonprofits on public funding in both countries, current cuts in government spending hit the sector in France and in Germany. In Germany, particularly nonprofits working at the local level in areas such as leisure or sports, which do not enjoy legally secured funding, face a difficult situation due to the fiscal constrains of German local governments that, quite often, is an important source of their funding. Small and medium-sized nonprofits are increasingly in a situation of fierce competition for local government grants and subsidies. Since in the near future, it is most likely that the financial crisis will have a stronger impact on Germany, local nonprofits will face a difficult time. Already today, membership is decreasing in local associations because Germans nowadays tend to avoid unnecessary expenditures such as membership dues for voluntary associations whose services are not often used. A downsizing of the nonprofit sector, less organizations with less members and reduced programs of leisure and sport activities might be the most likely outcome of the current situation.

The same holds true for those organizations, working in the core welfare domain such as in social services or health. Since the mid 1990s, the German government also follows a neoliberal agenda in social policy. A "privileged partnership" with nonprofits in the areas of social service provision is no longer perceived as a successful approach. Inline with costcutting strategies, "competition" among different providers of social services in a selected area, such as hospitals, seems to safeguard efficiency more effectively. Nonprofit hospital, homes for the elderly, children's homes and other facilities are faced with increasing competition from the for-profit sector in Germany. In order to be eligible for government grants, large and professionalized German nonprofits, active in the core welfare domain, have developed into highly efficient welfare enterprises. From a management point of view, today there is almost no difference between a nonprofit and for-profit social service provider.

However, although the German government increasingly treats nonprofits on equal footing with for-profit enterprises, the government still perceives the organizations as alternative tools for policy development. Textbook examples are programs that aim at integrating long-term unemployed, or government sponsored initiatives whose goal is a further integration of members of the migrant community in Germany. In other words, the organizations perceived as competitors in social markets which are increasingly tougher, and simultaneously, they are supposed to work on behalf of the common weal by running programs and initiatives which 
serve primarily those parts of the population that are in a very difficult situation, and who first and foremost have very little chances on the non-subsidized labour market. In sum: Currently, German government lacks a coherent policy towards the sector.

Again, the situation of nonprofits in France is similar. The financial crisis has already heavily affected the funding situation of many nonprofit organizations in France. The retrenchement of public money is for sure the hardest part of the crisis. The reduction of subsidies and contracts paid by the State is no longer being compensated by the regions, the départements or by local communities, all of which also have financial difficulties. Donations are steady despite tax incentives. During the early stages of the crisis, public grants or reimbursements were delayed and sometimes suppressed, provoking at best cash flow difficulties, and at worst bankruptcies along with the dismissal of employees in France. It has been the case for some home care services and nonprofits, active in the area of culture. Some French nonprofits have merged with other organizations working in the same field or area, or are pooling their infrastructure, equipment or human resources. However, it is likely that the French nonprofit sector will undergo a process of concentration. Instead, it is more likely that employment in the sector will decrease. Since 2010, nonprofit employment, indeed, is slightly decreasing, hence probably indicating a turning point in the continuous success story of welfare state enlargement and nonprofit growth.

All in all, the outlook towards future developments is rather pessimistic. It is most likely that the sector's success story, which by and large was a by-product of the growth of the welfare state might come to an end. There are indicators that nonprofit employment is on the decline. Furthermore, the quality of jobs in the sector is significantly deteriorating. Also the attractiveness of nonprofits for members is declining. The sector in both countries is confronted with a difficult situation, which asks for a new definition of its position vis a vis the state and the market.

\section{References:}

Alscher, Mareike/Dathe, Diemar/Priller, Eckhard/Speth, Rudolf (2009): Bericht zur Lage und zu den Perspektiven des bürgerschaftlichen Engagements in Deutschland, Berlin: WZB

Archambault, Edith (1997): The nonprofit sector in France, Manchester: Manchester Univ. Press: 324

Archambault, Edith (2001): Historical Roots of the Nonprofit Sector in France, in: Nonprofit and Voluntary Sector Quarterly, 130/2, June 2001: 204-230

Archambault, Edith /Jerome, Accardo, Jerome/Laouisset, Brahim (2010): Connaissance des associations, Report to the CNIS: 112

Bode, Ingo (2003): A New Agenda for European Charity: Catholic Welfare and Organizational Change in France and Germany, in: Voluntas, Vol.14, No. 2: 205-225

Boeßenecker, Karl-Heinz (2006): Spitzenverbände der Freien Wohlfahrtspflege. Eine Einführung in die Organisationsstrukturen und Handlungsfelder der deutschen Wohlfahrtsverbände, Weinheim/München: Juventus 
Bogumil, Jörg/Holtkamp, Lars (2006): Kommunalpolitik und Kommunalverwaltung, Wiesbaden: VS Verlag

Frey. Manuel (1999): Macht und Moral des Schenkens. Staat und bürgerliche Mäzene vom späten 18. Jahrhundert bis zur Gegenwart, Berlin: Fannei\&Walz

Henriksen, Lars Skov/Smith, Steven Rathgeb/Zimmer, Annette (2012): At the Eve of Convergence? Transormation of Social Service Provision in Denmark, Germany, and the United States, in: Voluntas, Vol 23, No 2: 458-501

Katzenstein, Peter J. (1987): Policy and politics in West Germany: the growth of a semisovereign state, Philadelphia: Temple Univ. Press

Krimmer, Holger (2011): Zivilgesellschaft in Zahlen, (6/24/2012): http://www.ziviz.info/fileadmin/download/krimmer_zivilgesellschaft_in_zahlen_projekt ergebnisse.pdf

Lehmbruch, Gerhard (1996): Der Beitrag der Korporatismusforschung zur Entwicklung der Steuerungstheorie, in: Politische Vierteljahresschrift, Heft 4: 735-751

Priller, Eckhard (2012): Scope, Structure, and Development of Civil Society in Germany, in: Zimmer, Annette (Eds.): Civil Societies Compared: Germany and the Netherlands, Baden-Baden: Nomos: in press

Prouteau, Lionel/Wolff, Jean-Charles (2004) Les bénévoles dans la vie associative, in Economie et Statistique, $\mathrm{N}^{\circ} 372: 2-39$

Prouteau, Lionel /Wolff, Jean-Charles, (forthcoming). Adhésions et dons aux associations : permanence et évolutions, Nantes, LEMNA WP 2012/25

Rosanvallon, Pierre (2004) Le modèle politique français. La société française contre le jacobinisme de 1789 à nos jours, Paris, Le Seuil

Rosenski, Natalie (2012): Die wirtschaftliche Bedeutung des Dritten Sektors. In: Statistisches Bundesamt, Wirtschaft und Statistik, März 2012: 209-217

Sachße, Christoph (1995): Verein, Verband und Wohlfahrtsstaat. Entstehung und Entwicklung der dualen Wohlfahrtspflege, in: Rauschenbach, Thomas/ Sachße, Christoph/Olk, Thomas (Eds): Von der Wertegemeinschaft zum Dienstleistungsunternehmen, Frankfurt: Suhrkamp Verlag 1995: 123-149

Sachße, Christoph (1996): Public and Private in German Social Welfare, in: Katz, Michal B./Sachße, Christoph (Eds.): The Mixed Economy of Social Welfare, Nomos: BadenBaden: 148-169

Salamon, Lester M. (1987): Partners in Public Service: The Scope and Theory of Government-Nonprofit Relations, in: Powell, Walter W. (Eds.): The Nonprofit Sector. A Research Handbook, New Haven: Yale Univ. Press: 99-117

Salamon, Lester M./Anheier, Helmut K. (1998): Social Origins of Civil society: Explaining the Nonprofit Sector Cross-Nationally, in: Voluntas, Vol.9, No 3: 213-248

Streeck, Wolfgang (1999): Vielfalt und Interdependenz: Überlegungen zur Rolle intermediärer Organisationen in sich ändernden Umwelten, in: Streeck, Wolfgang (Eds.): Korporatismus in Deutschland. Zwischen Nationalstaat und Europäischer Union, Frankfurt: Campus Verlag, 223-25Stiglitz Joseph, Sen Amaryata. et Fitoussi Jean-Paul. (2009) Rapport de la Commission sur la mesure de la performance économique et du progrès social, Paris, La Documentation française

Tchernonog, Viviane (2007): Le paysage associatif français. Mesures et évolution, Paris, Dalloz-Jurisassociations: 203

Zimmer, Annette (2001): Corporatism revisited. The legacy of history and the German nonprofit sector, in: Anheier, Helmut K./Kendall, Jeremy (Eds.): Third Sector Policy at the crossroads. An international nonprofit analysis, London/New York: Routledge: 114125

Zimmer, Annette (2007): Zivilgesellschaft konkret: Vereine, Wiesbaden: VS Verlag 
Zimmer, Annette/Appel, Anja/Dittrich, Claudia/Lange, Chris/Sitterman, Birgit/Stallmann, Freia/Kendall, Jeremy (2009): Chapter 2 Germany: On the social policy centrality of the Free Welfare Associations socio-political complex, in: Kendall, Jeremy (Ed.): Handbook on Third Sector Policy in Europe: Multi-Level Processes and Organised Civil Society, Aldershot: Edward Elgar: 21-42

Zimmer, Annette/Basic, Anton/Hallmann, Thorsten (2011): Sport ist im Verein am schönsten? Analysen und Befunde zur Attraktivität des Sports für Ehrenamt und Mitgliedschaft, in: Rauschenbach, Thomas/Zimmer, Annette (Eds.): Bürgerschaftliches Engagement unter Druck? Gemeinnützige Organisationen in den Bereichen Soziales, Kultur und Sport im politischen und gesellschaftlichen Wandel, Opladen: Barbara Budrich: 269-385

Zimmer, Annette/Priller, Eckhard (2007): Gemeinnützige Organisationen im gesellschaftlichen Wandel, Wiesbaden: VS-Verlag (2. Auflage)

Zivis (2011): Zivilgesellschaft in Zahlen, Modul 1. Endbericht, Statistisches Bundesmat und Centrum für soziale Investitionen und Innovationen 
Figure 1: Increase of the number of voluntary associations in Germany. 1960 - 2011

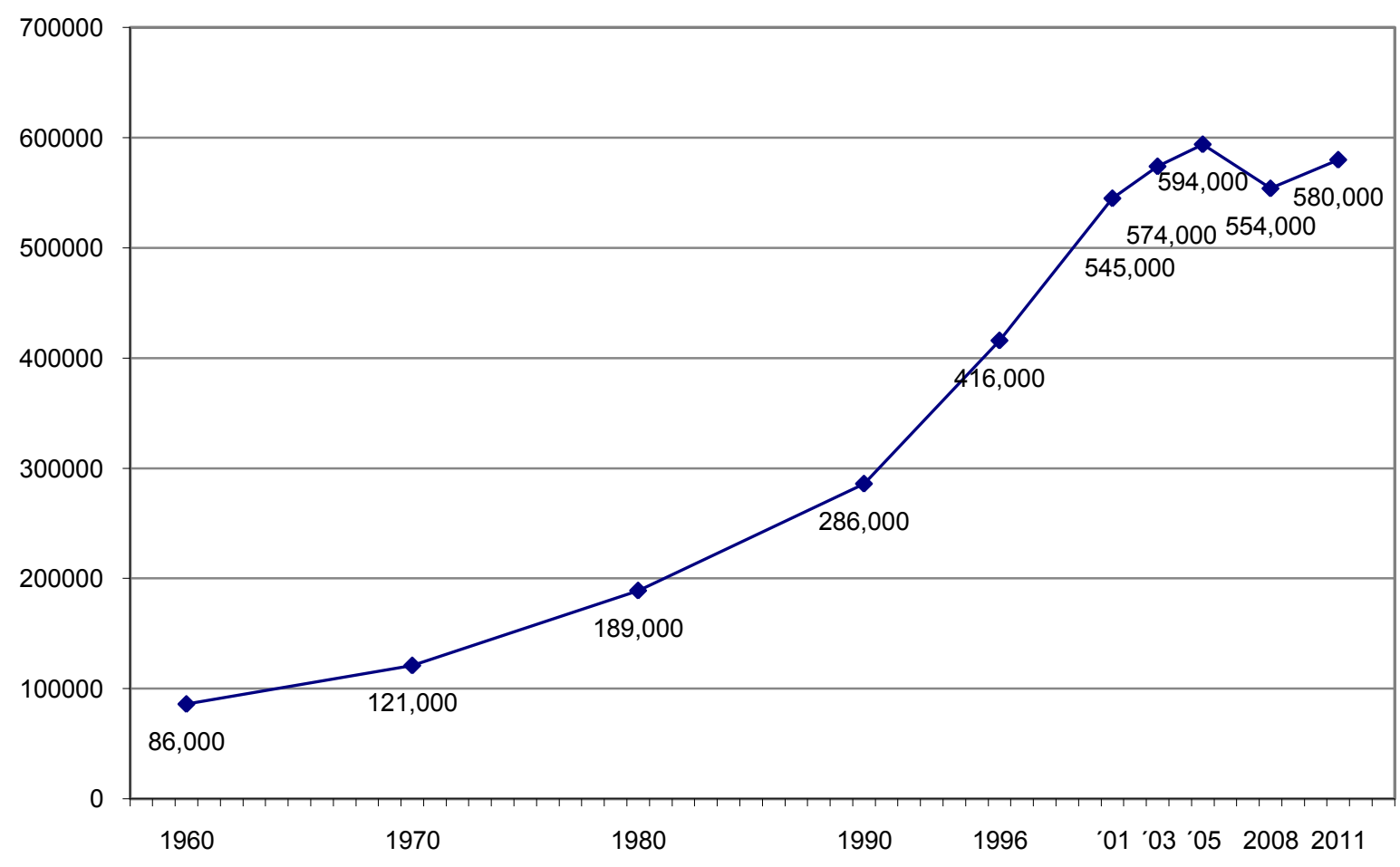

Sources: Johns Hopkins Comparative Nonprofit Sector Project, 2001-2011: V \&M Service $\mathrm{GmbH}$, Konstanz, Germany 
Figure 2: Annual Foundation of Associations, 1960 - 2011

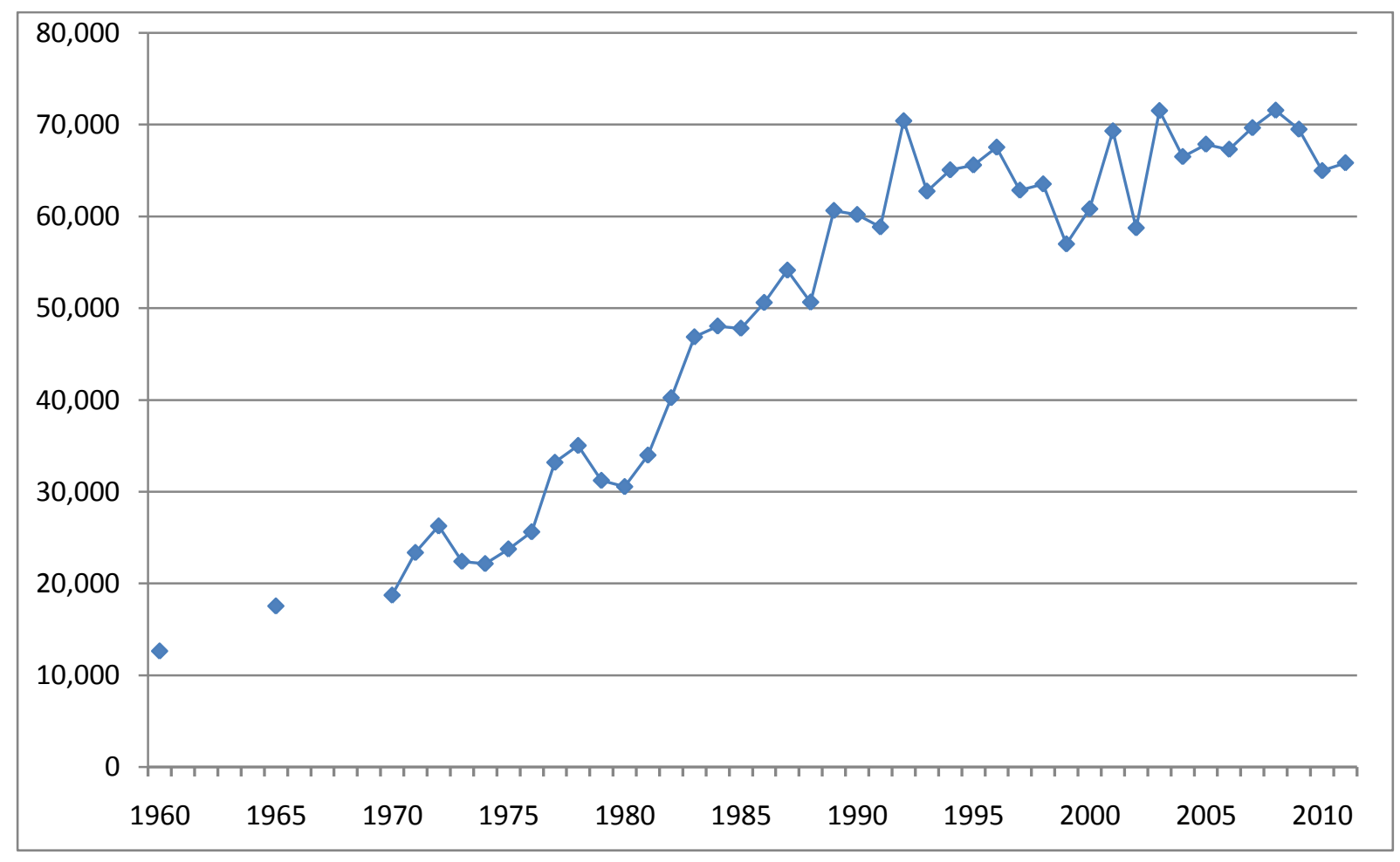

Source: Ministère de l'Intérieur, Journal officiel (except Departement Alsace-Moselle) 
Table 1: Nonprofit Organizations and Nonprofit Employment by Activity, $2009^{1}$

\begin{tabular}{|l|r|r|r|r|r|}
\hline Activity field & $\begin{array}{c}\text { Nonprofit } \\
\text { Organizations }\end{array}$ & Employees & $\begin{array}{c}\text { Full-time } \\
\text { Equivalents } \\
\text { (FTE) }\end{array}$ & $\begin{array}{c}\text { \% of total } \\
\text { nonprofit } \\
\text { FTE }\end{array}$ & $\begin{array}{c}\text { \% of total } \\
\text { activity } \\
\text { field FTE }\end{array}$ \\
\hline Health & 3900 & 152000 & 127000 & $\mathbf{8 . 2 \%}$ & $\mathbf{7 . 5 \%}$ \\
\hline Social services & 32120 & 868000 & 695000 & $\mathbf{4 4 . 8 \%}$ & $\mathbf{6 0 . 3 \%}$ \\
\hline $\begin{array}{l}\text { Culture, sports and } \\
\text { recreation }\end{array}$ & 56840 & 115000 & 93000 & $\mathbf{6 . 0 \%}$ & $\mathbf{3 9 . 5 \%}$ \\
\hline $\begin{array}{l}\text { Education, training and } \\
\text { research }\end{array}$ & 21650 & 346000 & 288000 & $\mathbf{1 8 . 5 \%}$ & $\mathbf{1 7 . 5 \%}$ \\
\hline $\begin{array}{l}\text { Other: Environment, } \\
\text { Advocacy, local } \\
\text { development, housing, } \\
\text { professional and nec }\end{array}$ & 70150 & 388000 & 330000 & $\mathbf{2 1 . 2 \%}$ & \\
\hline \multicolumn{1}{|c|}{ Total } & $\mathbf{1 8 4 8 6 0}$ & $\mathbf{1 8 6 9 0 0 0}$ & $\mathbf{1 5 3 3 0 0 0}$ & $\mathbf{1 0 0 . 0 \%}$ & $\mathbf{7 . 5 \%}$ \\
\hline
\end{tabular}

Source: INSEE, Tableaux harmonisés de l'Economie sociale

\footnotetext{
${ }^{1}$ Nonprofits include associations and foundations and do not include the nonprofit establishments run by mutuals. According to an agreement between INSEE and CNCRES to define the scope of social economy it does not incude worship organizations, political parties, labor unions, and business and trade unions despite their legal status is association..
} 
Figure 3: Areas of Nonprofit Activity and Gross Value Added (in\%)

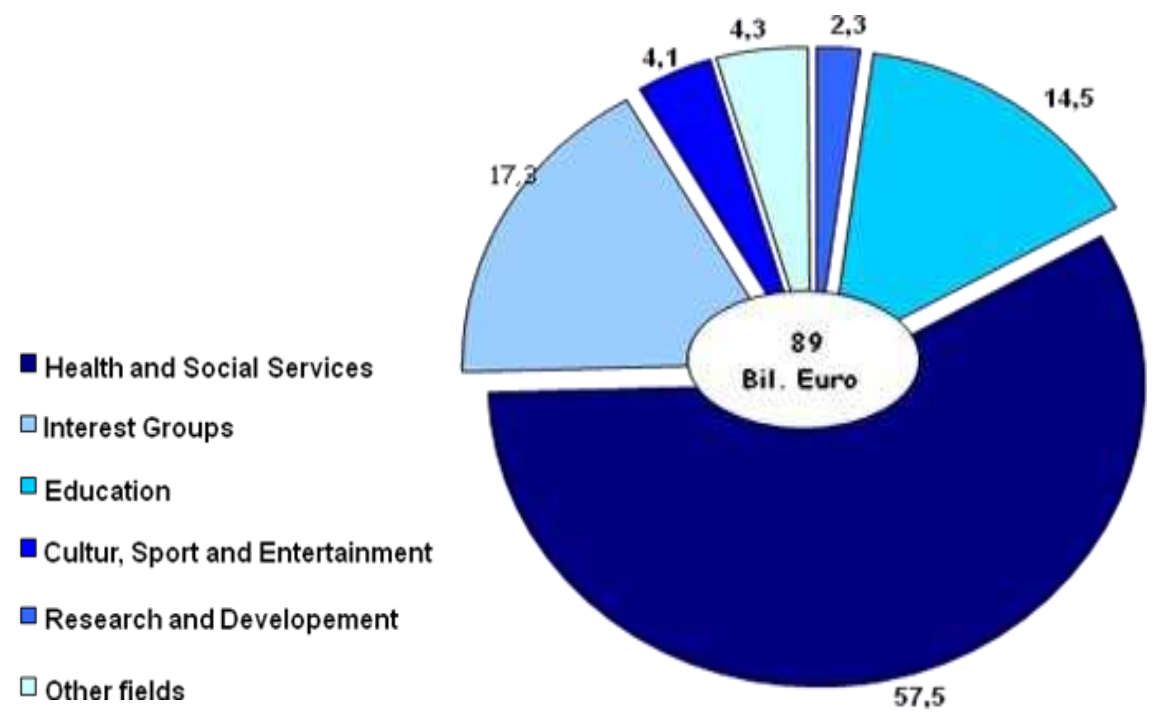

Source: Krimmer 2011: Zivilgesellschaft in Zahlen 
Table 2: Organizations and Areas of Activity of the German Welfare Associations, 2008

\begin{tabular}{|l|r|r|r|}
\hline Area of Service & Organizations & Full-time Employees & Part-time Employees \\
\hline Health care & 8,462 & 222,435 & 152,451 \\
\hline Youth & 38,092 & 146,018 & 179,955 \\
\hline Family & 7,201 & 16,029 & 45,470 \\
\hline Senior citizens & 16,524 & 152,750 & 246,164 \\
\hline People with disabilities & 15,365 & 125,815 & 165,492 \\
\hline $\begin{array}{l}\text { People in special social } \\
\text { situations }\end{array}$ & 7,782 & 13,765 & 13,936 \\
\hline Others & 7,329 & 25,625 & 22,279 \\
\hline Training Facilities & 1,638 & 6,086 & 7,559 \\
\hline Subtotal & $\mathbf{1 0 2 , 3 9 3}$ & $\mathbf{7 0 8 , 5 2 3}$ & $\mathbf{8 3 3 , 3 0 6}$ \\
\hline $\begin{array}{l}\text { Self-help and community } \\
\text { service groups }\end{array}$ & 34,817 & 2,347 & 4,419 \\
\hline \multicolumn{1}{|c|}{ Grand total } & 137,210 & 710,870 & 837,725 \\
\hline
\end{tabular}

Source: $\quad$ Bundesarbeitsgemeinschaft der Freien Wohlfahrtspflege e.V. (BAGFW) (2009). Einrichtungen und Dienste der Freien Wohlfahrtspflege. Gesamtstatistik 2008 
Table 3: Nonprofit Employment in Germany

\begin{tabular}{|l|c|c|c|}
\hline & $\begin{array}{c}1990 \\
\text { (without former } \\
\text { East-Germany) }\end{array}$ & 1995 & 2007 \\
\hline Nonprofit Employees (in Mio.) & 1,3 & 2,1 & $2,3^{*}$ \\
\hline $\begin{array}{l}\text { Share of Nonprofit Employment of total } \\
\text { Employment (in \%) }\end{array}$ & 3,74 & 4,93 & 9,0 \\
\hline
\end{tabular}

* part- and full-time employment

Source: Johns Hopkins Comparative Project \& Rosenski 2012 
Figure 4: Women, part-time, and temporary employees in Germany's labor force, 1996 and 2008 in \%

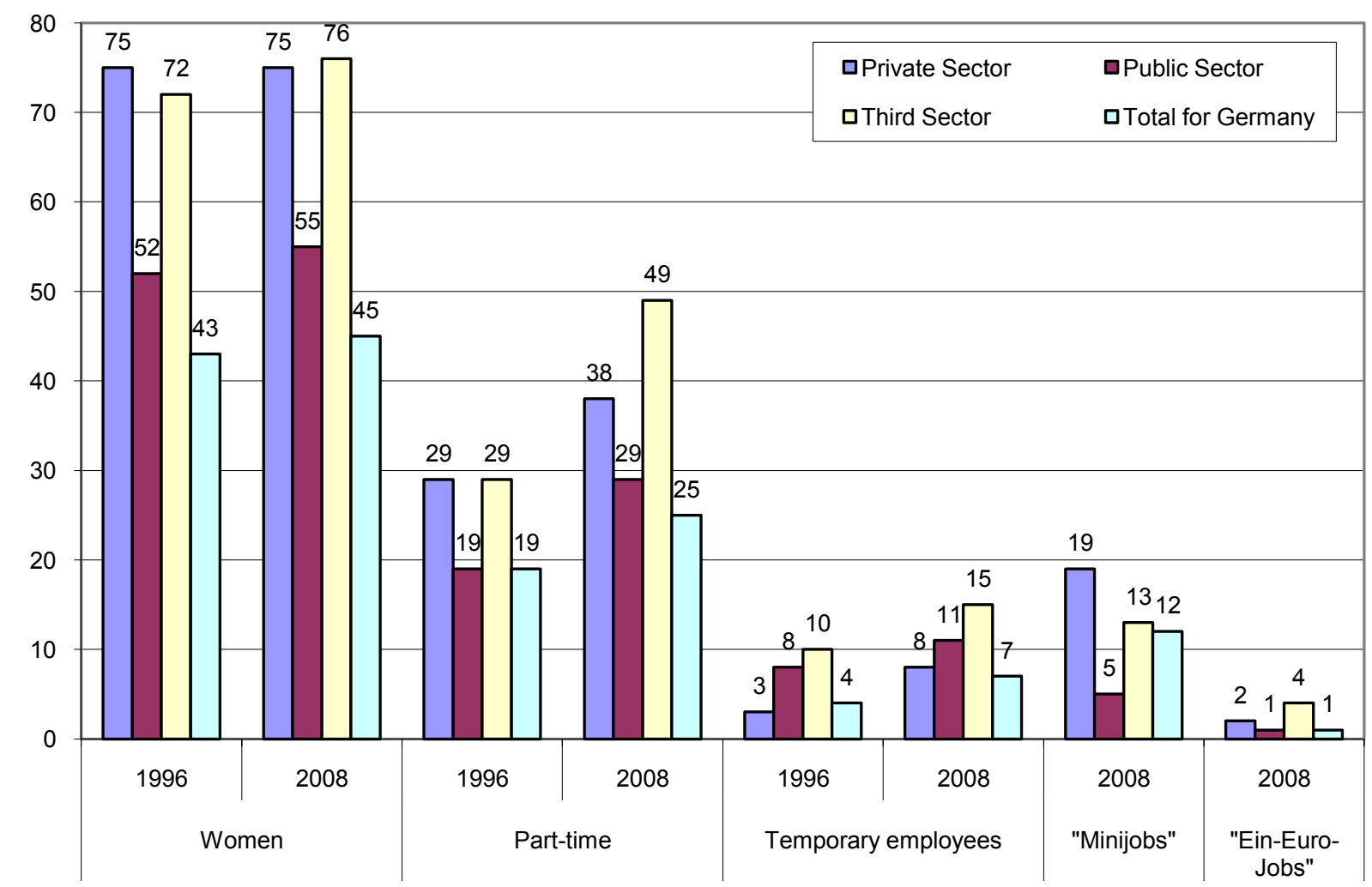

Source: $\quad$ IAB Establishment Panel, 1996-2008. 
Figure 5: Revenue sources by subsector, 1995 France

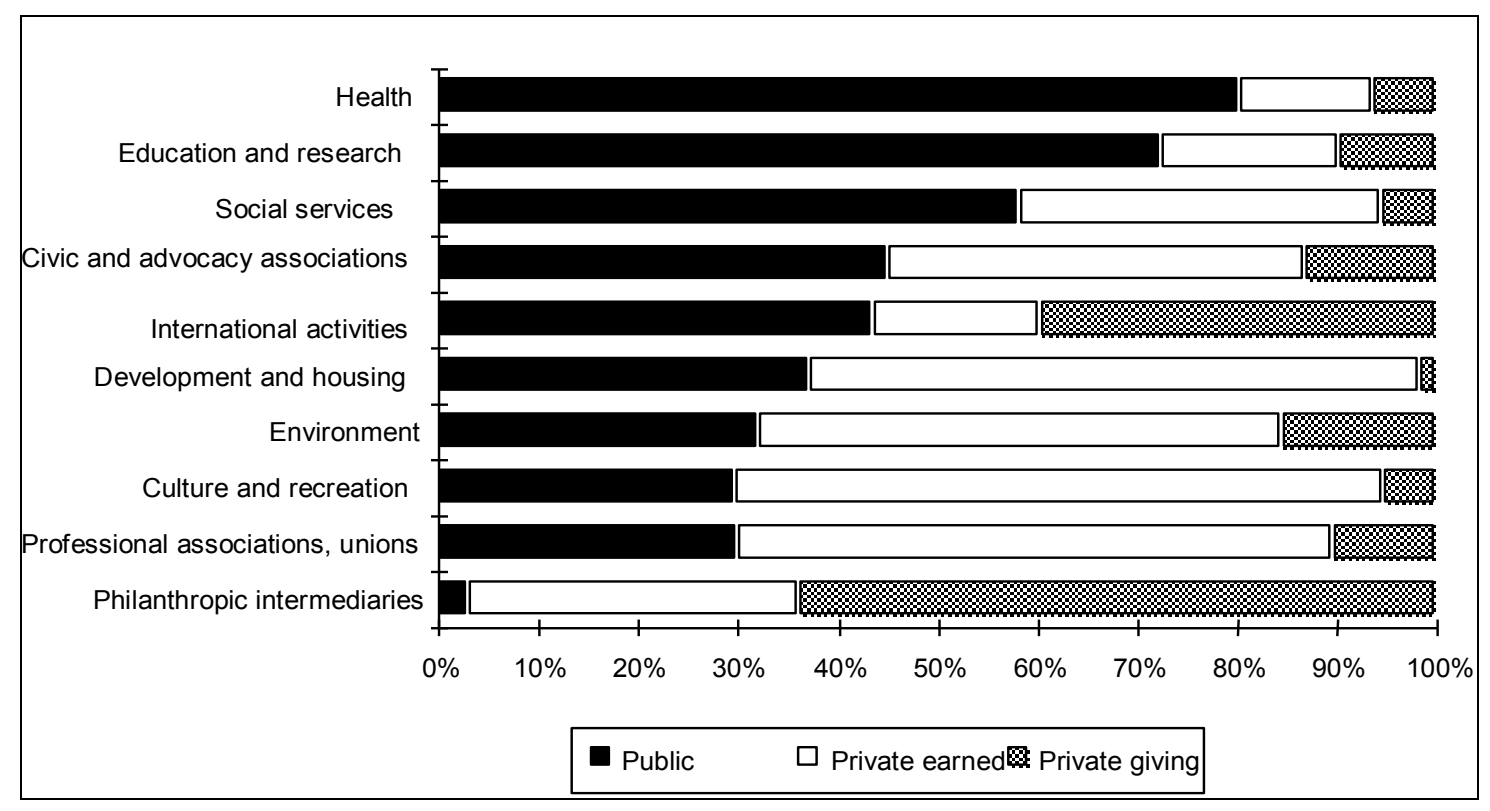

Source: Johns Hopkins Nonprofit Sector Comparative Project - Phase 2 
Figure 6: Revenues of Nonprofit Organizations in 1995 (in percent), Germany

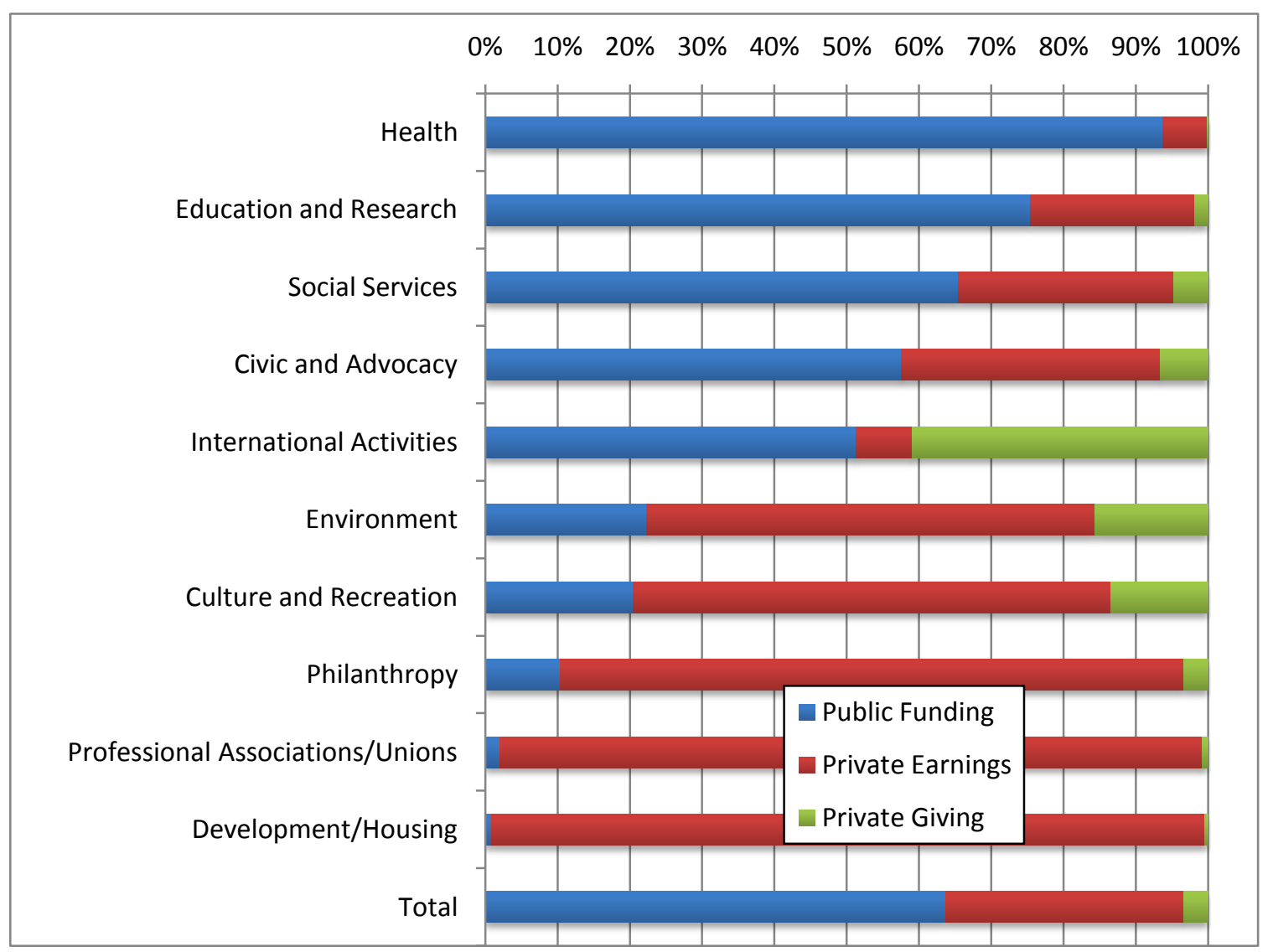

Source: Johns Hopkins Comparative Nonprofit Sector Project 
Table 4: Development of Volunteering in France, 1990 - 2010

\begin{tabular}{|l|c|c|c|c|c|}
\hline & $\mathbf{1 9 9 0}$ & $\mathbf{1 9 9 3}$ & $\mathbf{1 9 9 6}$ & $\mathbf{2 0 0 2}$ & $\mathbf{2 0 1 0}$ \\
\hline volunteers (millions) & 7.9 & 9.0 & 10.4 & 12 & 16,1 \\
\hline $\begin{array}{l}\text { volunteers } \\
\text { in \% of adult population }\end{array}$ & $\mathbf{1 9 \%}$ & $\mathbf{2 1 \%}$ & $\mathbf{2 3 \%}$ & $\mathbf{2 6 \%}$ & $\mathbf{3 2 \%}$ \\
\hline
\end{tabular}

Sources: France - 3 Surveys LES/ISL/JHCNP for 1990, 1993 and 1996; INSEE 2002; DREES-BVA for 2010. 
Figure 7: Development of Volunteering in Germany, 1985 - 2009

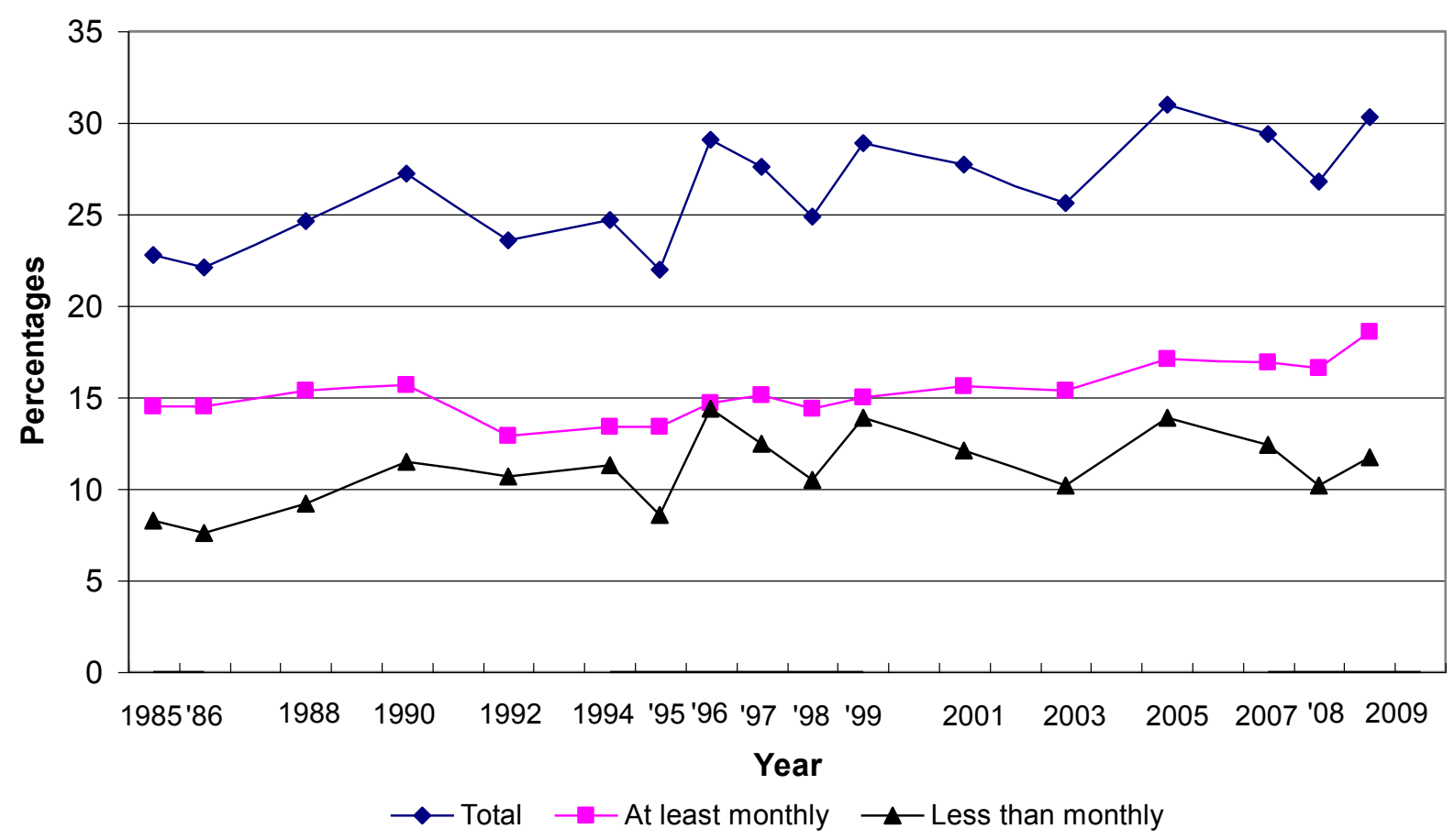

Source: Priller 2012: forthcoming 
Figure 8: Volunteering in Germany by activity field, 1999, 2004, and 2009, in percent of overall volunteering

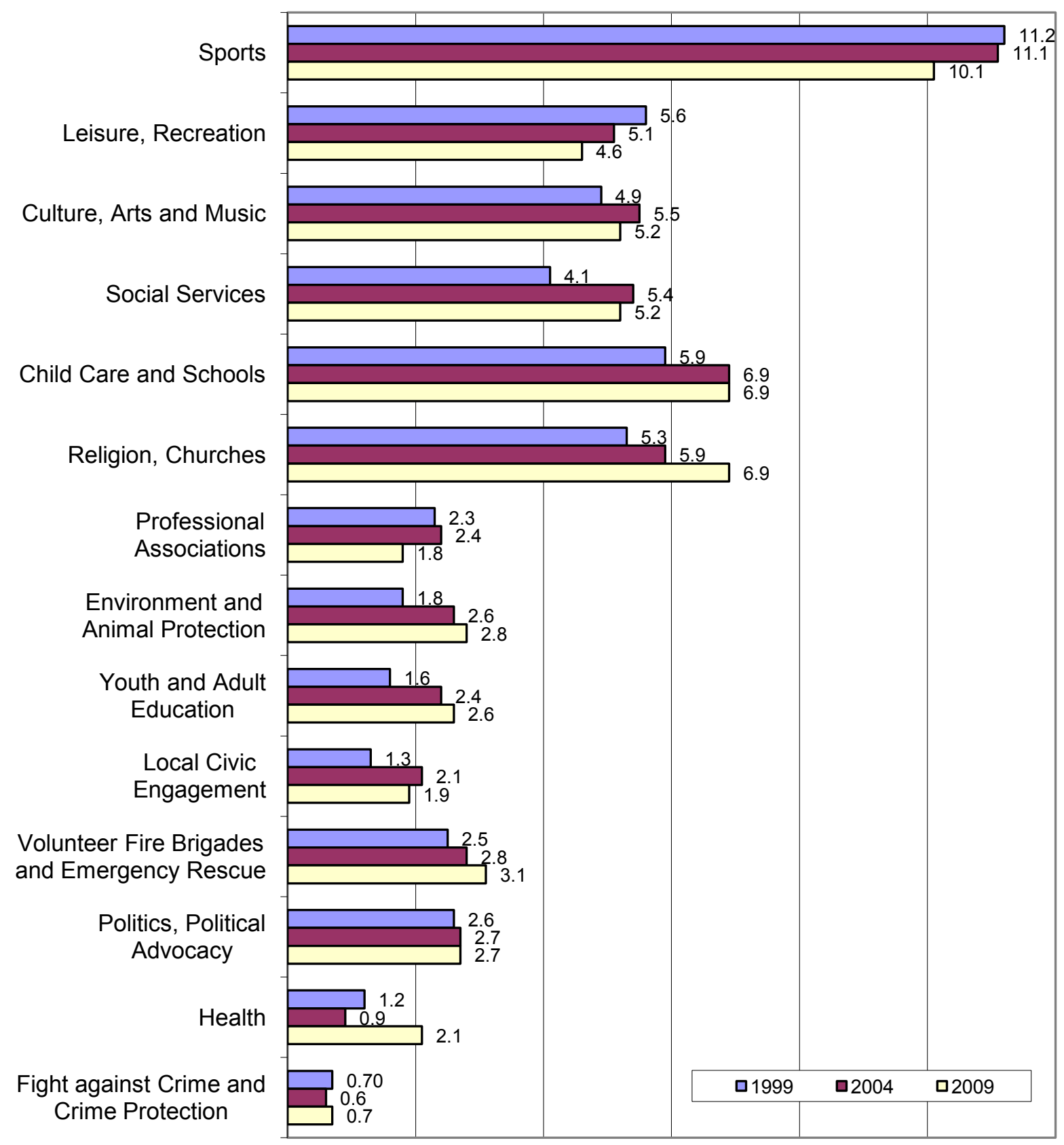

Source: Freiwilligensurvey 
Figure 9: Membership Quota in Voluntary Associations (Clubs) in European Countries

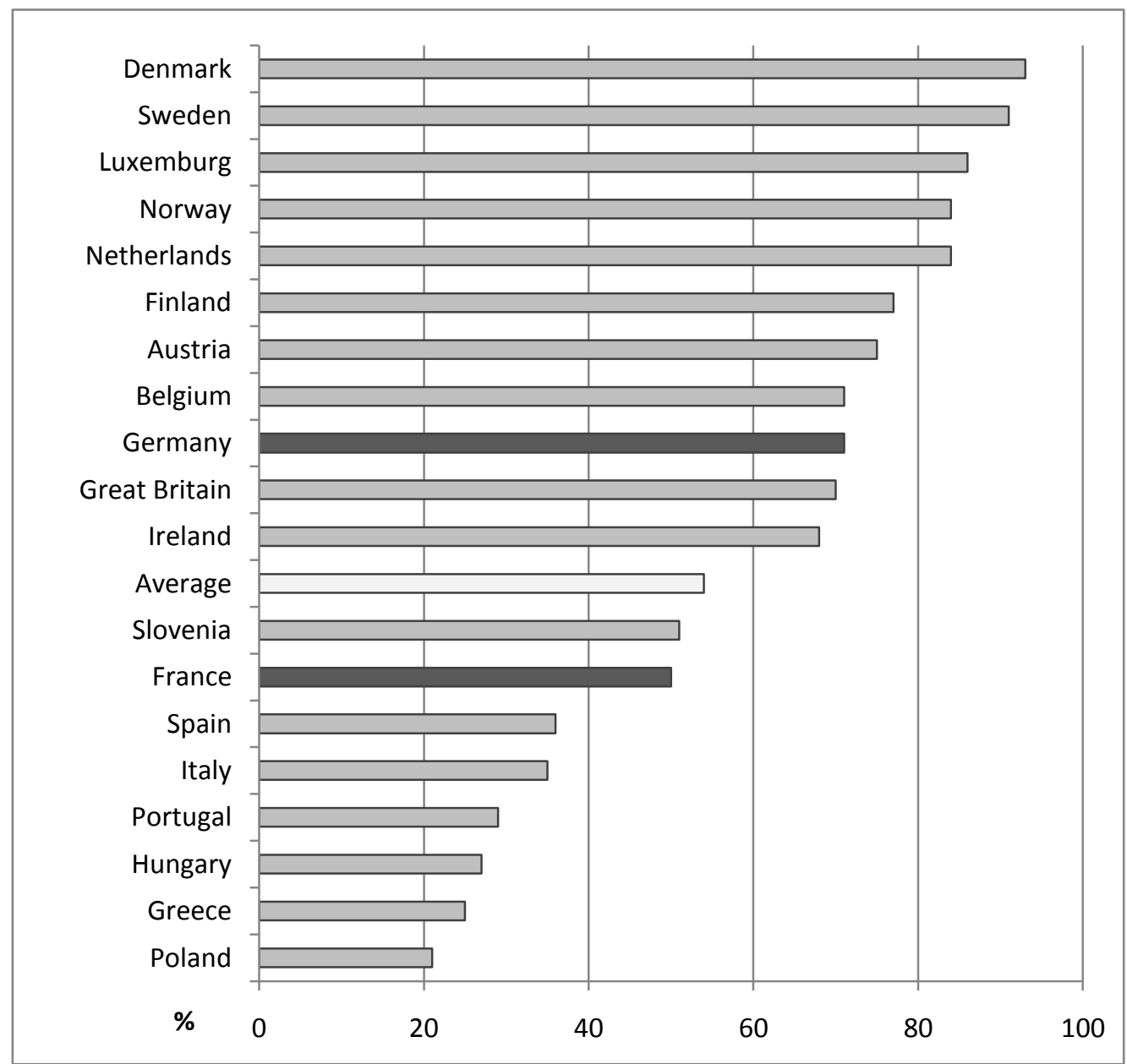

Source: European Social Survey 2002/2003 
Figure 10: Quota of Donators in European Countries

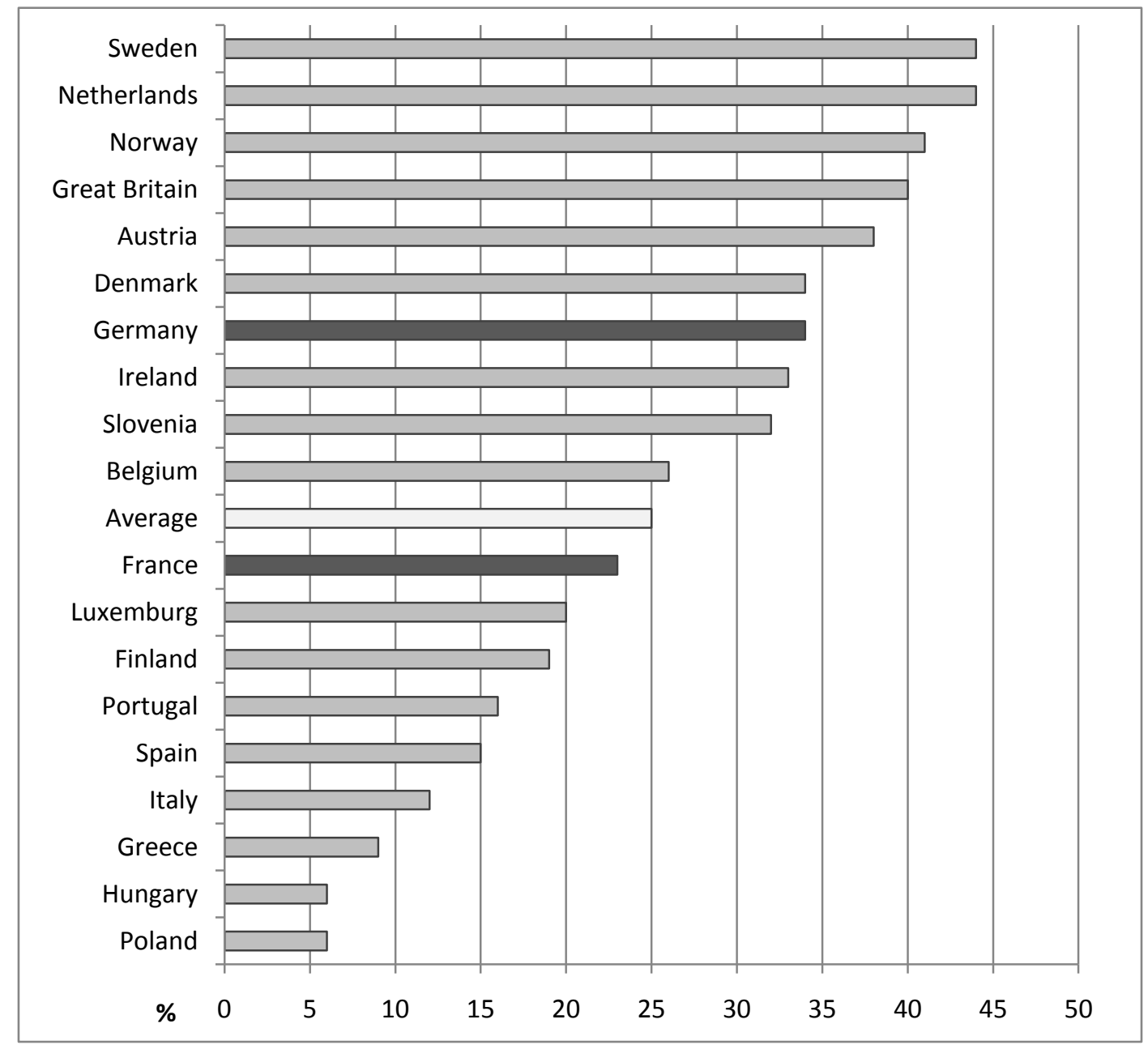

Source: European Social Survey 2002/2003 
Figure 11: Number of new Foundations in Germany, 1990-2011

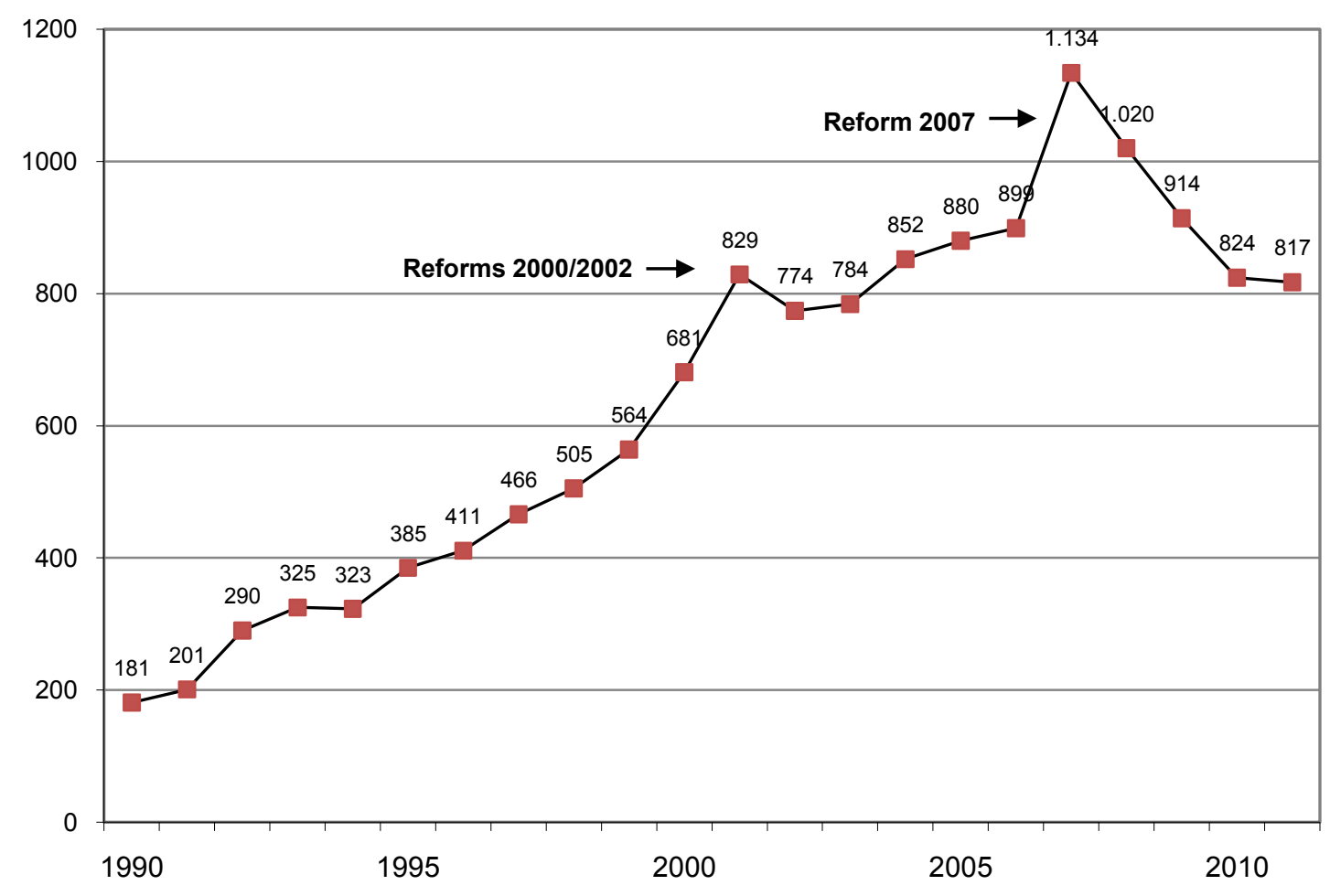

Source: $\quad$ Prilller 2012 